\title{
Restrictive Immigration Policy in Germany: Pains and Gains Foregone?
}

\author{
GABRIEL FELBERMAYR \\ WIDO GEIS \\ WILHELM KOHLER
}

CESIFO WORKING PAPER NO. 2316

CATEGORY 4: LABOUR MARKETS

MAY 2008
An electronic version of the paper may be downloaded
- from the SSRN website:
- from the RePEc website:
www.SSRN.com
- from the CESifo website:
www.RePEc.org
www.CESifo-group.org/wp




\title{
Restrictive Immigration Policy in Germany: Pains and Gains Foregone?
}

\begin{abstract}
Many European countries restrict immigration from new EU member countries. The rationale is to avoid adverse wage and employment effects. We quantify these effects for Germany. Following Borjas (2003), we estimate a structural model of labor demand, based on elasticities of substitution between workers with different experience levels and education. We allow for unemployment which we model in a price-wage-setting framework. Simulating a counterfactual scenario without restrictions for migration from new EU members countries, we find moderate negative wage effects, combined with increased unemployment for some types of workers. Wage-setting mitigates wage cuts.
\end{abstract}

JEL Code: F2, J01.

Keywords: migration, labor.

\author{
Gabriel Felbermayr \\ Eberhard Karls University Tübingen \\ Nauklerstrasse 47 \\ 72074 Tübingen \\ Germany \\ gabriel.felbermayr@uni-tuebingen.de
}

\author{
Wido Geis \\ Ifo Institute for Economic Research at \\ the University of Munich \\ Poschingerstrasse 5 \\ 81679 Munich \\ Germany \\ geis@ifo.de
}

\author{
Wilhelm Kohler \\ Eberhard Karls University Tübingen \\ Nauklerstrasse 47 \\ 72074 Tübingen \\ Germany \\ wilhelm.kohler@uni-tuebingen.de
}

We are grateful for financial support from the Fritz Thyssen Foundation under grant Az. 10.06.1.111. Thanks are due to Herbert Brücker, Davide Sala, and Richard Upward for helpful discussion. 


\section{Introduction}

The treaties regulating the entry of 12 Central- and Eastern European countries (CEECs) into the European Union enable incumbent member states to disallow free immigration of workers from these new member countries for a maximum of 7 years. ${ }^{1}$ The majority of countries have opted for such transitional restrictions. In 2004, the United Kingdom, Ireland, and Sweden were the only exceptions, and when Bulgaria and Romania became members in 2007 the UK and Ireland also used transitional agreements. Germany, the largest and closest country to those new members, has been particularly strict.

What is the economic rationale for transitional restrictions? Why did countries choose different policies? One way to make sense of this is to read revealed policy preferences into the policies chosen. According to this interpretation, the 'liberal countries' have expected labor inflows in the immediate aftermath of enlargement to generate gains that outweigh the pains from labor market adjustment, while the 'restrictionist incumbents' have feared more painful labor market adjustment that dwarfs the expected gains. Equivalently, they may also have attached a larger weight to alleged pains in their policy preferences. Being transitional, however, the restrictive policy assumes that the economy would later be in a position to better absorb immigration on the labor market, or that postponement would lead to a more advantageous magnitude and/or pattern of the labor inflow.

The potential gains and pains from immigration are easily identified in principle, but difficult to quantify empirically. Arguably, new immigrants carry an almost zero weight in policy formation. Natives as a whole stand to gain from an inflow of foreign workers that is complementary to factors supplied domestically by natives. This is the well known immigration surplus; see Borjas (1994) or, for a generalization, Felbermayr and Kohler (2007). However, in certain segments of the labor market foreign workers are likely to be a close substitute for natives who will then experience downward wage pressure. Hence, the immigration surplus comes with distributional effects that may be unwelcome from a political economy perspective, or may be difficult to deal with through compensation. In addition, to maintain full employment, absorption of foreign workers typically requires costly reallocation of native workers. More likely for European countries, labor market

\footnotetext{
${ }^{1}$ On May 1st of 2004, Cyprus, the Czech Republic, Estland, Hungary, Latvia, Lituania, Malta, the Slovak Republic, and Slovenia have joined the EU. Bulgaria and Romania have followed on January 1st of 2007.
} 
imperfections may cause an increase in native unemployment, especially in the short-run. And finally, with complex welfare systems in place, an inflow of foreign workers has fiscal implications that may or may not be to the benefit of natives.

In this paper, we propose an empirical approach to identify the gains and pains that the German economy has forgone by opting for transitional restrictions on immigration. Our approach relies on three steps. First, we estimate structural labor demand functions for different types of labor, defined on the basis of workers' educational attainment, their experience, and their status as either immigrants or natives. We rely on the structural approach recently proposed by Borjas (2003) and others in an attempt to overcome the endogeneity concerns present in earlier approaches. However, in line with more recent work by Ottaviano \& Peri (2006) and Manacorda et al. (2007), we allow for imperfect substitution between native and foreign labor. More importantly, we allow for non-Walrasian labor market institutions when estimating structural labor demand parameters. ${ }^{2}$

In a second step, we enhance the empirical strategy by an explicit treatment of wagesetting institutions that are responsible for unemployment. More specifically, we estimate a wage-setting equation along the lines suggested by Layard, Nickell \& Jackman (2005). This allows us to place the Borjas-approach in a more general framework, taking into account an institutional environment that generates high and persistent unemployment, and thus to simultaneously determine wage and unemployment effects of immigration. We apply our econometric strategy to combined data from the German Socioeconomic Panel (GSOEP) and the German micro census.

The third step combines our econometric estimates of labor demand as well as wage setting, in order to address a counterfactual migration scenario by means of numerical simulation. We define a counterfactual that relates to the aforementioned transitional agreements of eastern EU-enlargement. More specifically, we look at immigration that would likely have obtained if, instead of opting for transitional import restrictions, Germany had chosen a liberal policy stance, as was the case in the UK. Our results depict the detailed wage and employment effects that would have obtained from the additional inflow of workers from new member countries that Germany has avoided through transi-

\footnotetext{
${ }^{2}$ Using US data Ottaviano \& Peri (2007) also allow for imperfect substitutability between natives and immigrants. The standard Borjas (2003) approach has been extended by Aydemir \& Borjas (2007) to Canada and Mexico, and by Manacorda, Manning \& Wadsworth (2007) to Britain. Using German data, Bonin (2005) estimates partial equilibrium effects of immigration.
} 
tional restrictions. This is the pains side of the exercise. Following Felbermayr \& Kohler (2007), we then map the wage and employment effects into forgone welfare gains.

Our paper is related to Brücker \& Jahn (2008) and D'Amuri et al. (2008), who also attempt to address German immigration scenarios based on a combination of structural labor demand equations allowing for unemployment effects. We shall point out the similarities and differences in more detail below. At this point, the distinctive features of our paper may be summarized as follows. First, we use household survey data from the German Socio-Eeconomic-Panel (SOEP) that avoids certain problems arising with socialsecurity-based data used by these other papers. Second, before turning to a simulation exercise, we portray a detailed picture of education-experience-based complementarity and substitutability, respectively between native and foreign labor. This incorporates policy-relevant information in a general way, independently of any specific immigration scenario. Thirdly, in our simulation exercise we address a specific immigration scenario which seems particularly relevant against the backdrop of eastern enlargement of the EU, and we do so using both wage-setting as well as labor demand parameters that are consistently estimated on the same original German data set.

The next section introduces our conceptual framework. It describes our structural view of labor demand which is amenable for empirical implementation, followed by a discussion of endogeneity concerns that arise in the econometric estimation of inverse labor demand functions, and then augments the empirical framework by incorporating a reduced form version of the Layard-Nickell-Jackman (LNJ) model of price-wage-setting. Section 3 discusses main advantages as well as potential problems of our data. Section 4 turns to the empirical results, and it comes in two parts. The first presents estimation results for the structural inverse labor demand functions, including a detailed picture of complementarity and substitutability between native and foreign labor, as well as for the reduced form of the price-wage-setting model. The second part uses these parameter estimates to simulate a specific immigration scenario. The scenario depicts the counterfactual case of a liberal German policy stance on immigration from new members, abstaining from the option of transitional restrictions in the recent eastern enlargement of the EU. Section 5 concludes the paper. 


\section{Conceptual Framework}

Immigration must be seen as positive labor supply shock to the receiving country. The effect on natives, as a group as well as on individuals, depends on the size and composition of the labor inflow. Intuition and empirical evidence (see Card \& Lemieux, 2001) suggest that education and experience are among the key characteristics that determine a worker's labor market performance. Accordingly, the education $\times$ experience pattern of foreign workers will matter for how native workers are affected by immigration. ${ }^{3}$ Suppose, then, that $\mathbf{N}$ and $\mathbf{M}$, respectively, are vectors of native and immigrant labor supply with the relevant education $\times$ experience characteristics. With perfect domestic labor markets, the native wage effects of a given flow of immigrants $\mathrm{d} \mathbf{M}$ is given by $\mathrm{d} \mathbf{w}^{N}=Y_{\mathbf{N M}} \mathrm{dM}$, where $\mathbf{w}^{N}$ denotes wages for native workers and $Y_{\mathbf{N M}}$ is the matrix of second order derivatives of the receiving country's GNP-function $Y(\mathbf{N}, \mathbf{M}, \mathbf{p})$, evaluated at the initial levels of $\mathbf{N}$ and M. For simplicity, we assume constant goods prices $\mathbf{p}$. It can be shown that immigration is beneficial to natives as a group if $\mathbf{N}^{T} \mathrm{~d} \mathbf{w}^{N}=\mathbf{N}^{T} Y_{\mathbf{N M}} \mathrm{dM}>0$, where $T$ denotes a vector transposition (see Felbermayr \& Kohler, 2007). If this condition holds, then we may say that the immigration flow $\mathrm{dM}$ is complementary, in the aggregate, to native labor $\mathbf{N}$. Whether or not it is satisfied depends on the interaction between the general equilibrium elasticities behind $Y_{\mathbf{N M}}$ and the specific composition of the inflow $\mathrm{dM}$. In this paper we pin down empirically the matrix $Y_{\mathbf{N M}}$, and calculate $\mathrm{d} \mathbf{w}^{N}$ as well as $\mathbf{N}^{T} \mathrm{~d} \mathbf{w}^{N}$ for a certain foreign labor inflow dM.

However, to bring this calculus to German data requires departing from the assumption of perfect labor markets which underlies the GNP-function. Our approach combines two fundamental notions. The first, also incorporated in the GNP-function approach, is that for any education $\times$ experience-segment of the labor market, employment is subject to the condition that the marginal value productivity is equal to the ongoing wage rate. This is incorporated in our framework through education $\times$ experience-related inverse labor demand functions, based on a macroeconomic production function as proposed by Borjas (2003). Securing consistent estimates of such labor demand functions is an important cornerstone of our approach. The second notion, which departs from the conven-

\footnotetext{
${ }^{3}$ This is also reflected by the role that these characteristics play in almost all immigration countries' restrictive quota systems (see UN-DESA, 2004, and OECD, 2007). Therefore, our approach features a disaggregate view of the labor market along the education $\times$ experience dimension.
} 
tional GNP-approach, is that wages are set in a non-market-clearing way by labor market institutions. Abstaining from detailed modeling of these institutions, we assume that wage-setting takes into account the degree of unemployment within and across segments of the labor market in a way that allows for unemployment. We implement this through a suitable modification of the well-known "price-wage-setting" framework that has been proposed by Layard, Nickell \& Jackman (2005) - henceforth referred to as LNJ - in order to understand European unemployment.

More specifically, we interpret our inverse labor demand functions as "normal-costpricing" equations within the LNJ-framework. ${ }^{4}$ Thus, firms are assumed to always be on their labor demand functions, derived from the marginal productivity of labor. This amounts to assuming a rights-to-manage environment. Adding LNJ-type wage-setting equations for all our labor-market-segments generates a consistent set-up which inherits all the advantages of the Borjas-approach (see below), while at the same time allowing for European-type unemployment. In particular, if wage-setting does not clear the labor market, then a foreign worker supply change through an inflow dM will lead to employment changes $\mathrm{d} \mathbf{L}^{M}(\mathrm{~d} \mathbf{M}) \leq \mathrm{d} \mathbf{M}$ and $\mathrm{d} \mathbf{L}^{N}(\mathrm{~d} \mathbf{M}) \leq \mathrm{d} \mathbf{N}=\mathbf{0}$. We derive these employment changes from reduced form estimates of the education $\times$ experience-based LNJ-framework (see below). We then return to our inverse labor demand functions, in order to calculate the associated wage effects $\mathrm{d} \mathbf{w}^{N}=\tilde{\mathbf{L}}_{\mathbf{N}}^{N} \mathrm{~d} \mathbf{L}^{N}(\mathrm{~d} \mathbf{M})+\tilde{\mathbf{L}}_{\mathbf{M}}^{N} \mathrm{~d} \mathbf{L}^{M}(\mathrm{~d} \mathbf{M})$, where $\tilde{\mathbf{L}}_{\mathbf{N}}^{N}$ and $\tilde{\mathbf{L}}_{\mathbf{M}}^{N}$ denote the respective gradients of the estimated inverse labor demand functions. By complete analogy, we may derive $\mathrm{d}_{\mathbf{w}}{ }^{M}$. Welfare effects then follow by analogy to the above, taking into account that native income is affected not only through wage effects, but also through employment effects $d \mathbf{L}^{N}(\mathrm{~d} \mathbf{M})$. In what follows we first describe the conceptual framework that allows us to estimate, in elasticity form, the gradients $\tilde{\mathbf{L}}_{\mathbf{N}}^{N}$ and $\tilde{\mathbf{L}}_{\mathbf{M}}^{N}$. Subsequently, we show how these are combined with the reduced-form-estimation of a disaggregate LNJ-model so that we may then calculate $\mathrm{d} \mathbf{L}^{N}(\mathrm{~d} \mathbf{M})$ and $\mathrm{d} \mathbf{L}^{M}(\mathrm{~d} \mathbf{M})$, as well as the wage effects $d \mathbf{w}^{N}$ and $d \mathbf{w}^{M}$ for a suitable scenario of immigration $\mathrm{dM}$.

\footnotetext{
${ }^{4}$ Normal-cost-pricing simply refers to the case of perfect competition within the LNJ-framework, which is usually presented with markup-pricing on gods markets; see Layard, Nickell \& Jackman (2005, ch. 1). The fact that the LNJ-framework is amenable to a straightforward labor demand and supply interpretation is also emphasized by Blanchard (2007, p. 411).
} 


\subsection{A structural model of labor demand}

Our approach, borrowed from Borjas (2003), and based on ample empirical labor market evidence, stresses the level of educational attainment and experience for wages of workers. ${ }^{5}$ In what follows, we use $e \in \mathcal{E}$ to denote educational attainment $e$, where $\mathcal{E}=\{1, \ldots, E\}$ and $E$ denotes the number of educational classes considered. By analogy $x \in \mathcal{X}$ denotes experience level $x$, with $\mathcal{X}=\{1, \ldots, X\}$. In our case $E=X=4$ (see below). In the aggregate, complementarity in the sense described above then arises from an education $\times$ experience-composition of the inflow that differs from native labor, in addition to the complementarity between labor and other factors owned by natives, like capital; see Berry \& Soligo (1969) and Borjas (1995,1999). With a certain stock of pre-existing foreign labor, however, altering the composition of the labor force is not sufficient for immigration to be gainful for natives as a whole; see Felbermayr \& Kohler (2007). Moreover, with unemployment what counts is not the change in the labor force, but a change in employed labor. The Borjas-approach towards a structural model of labor demand allows us to capture the mere technology-based relationships of complementarity and substitutability, respectively, between employment of workers with different education $\times$ experience characteristics. ${ }^{6}$ It is the first building block of our numerical policy simulation, to be complemented by the reduced form version of a non-market-clearing model of wage setting which allows us to relate employment to labor supply.

We need a framework which is amenable for empirical estimation. This requires a suitably parsimonious parameterization of labor demand. Building on Card \& Lemieux (2001), Borjas (2003) suggests a nested CES-parameterization. Theoretical models that look only at aggregate labor often assume foreign and domestic labor to be imperfect substitutes, the implicit assumption being that the two types of labor differ in relevant labor market characteristics; see for instance Ethier (1985). But this may still mask

\footnotetext{
${ }^{5}$ The approach goes back to Card \& Lemieux (2001) and has been used in the migration context by Borjas (2003), Ottaviano and Peri (2005, 2006), Manacorda et al. (2006), and Aydemir and Borjas (2007).

${ }^{6}$ Complementarity here means what Hamermesh (1993) calls q-complementarity (q for quantity): A rise in the wage for a certain type of labor upon an increase in supply of some other type of labor. Discussing partial equilibrium relationships, he defines an elasticities of q-complementarity by holding all other factor inputs and the price of the output constant. We shall develop general equilibrium analogues to these elasticities below.
} 
significant differences across workers. We therefore follow Ottaviano \& Peri (2006) in allowing native and foreign workers with the same education $\times$ experience characteristic to be different inputs into production, with a finite elasticity of substitution. ${ }^{7}$ Using $L_{t e x}^{N}$ and $L_{t e x}^{M}$ to denote employment of natives and natives, respectively, with education level $e$ and experience $x$ at time $t$, we stipulate the lowest CES nest as

$$
L_{e x}=\left[\lambda_{e x}^{N}\left(L_{e x}^{N}\right)^{\frac{\sigma_{e}^{M}-1}{\sigma_{e}^{M}}}+\left(1-\lambda_{e x}^{N}\right)\left(L_{e x}^{M}\right)^{\frac{\sigma_{e}^{M}-1}{\sigma_{e}^{M}}}\right]^{\frac{\sigma_{e}^{M}}{\sigma_{e}^{M}-1}} .
$$

Native and foreign workers thus combine to generate a composite $e x$-type labor input $L_{e x}$ according to a constant elasticity of substitution $\sigma_{e}^{M}$, which is allowed to differ across levels of education. The labor-composite $L_{e x}$ is homogeneous across all possible domestic uses. Equating the wage rate to the marginal productivity of labor, we arrive at a conditional inverse labor demand equation $w_{e x}^{N}=p_{e x} \lambda_{e x}^{N}\left(L_{e x} / L_{e x}^{N}\right)^{1 / \sigma_{e}^{M}}$, where $p_{e x}$ is the shadow price of composite labor $L_{e x}$ which is, in turn, equal to the marginal productivity of $L_{e x}$ in domestic production. An analogous expression holds for the immigrant wage rate $w_{e x}^{M}$.

With constant $L_{e x}^{N}$ and $p_{e x}$, we have $\operatorname{dln} L_{e x}=s_{e x}^{M} \mathrm{~d} \ln L_{e x}^{M}$ and $\operatorname{dln} w_{e x}^{N}=\left(s_{e x}^{M} / \sigma_{e}^{M}\right) \mathrm{d} \ln L_{e x}^{M}$, where $s_{e x}^{M}$ is the elasticity of $L_{e x}$ with respect to $L_{e x}^{M}$, which is equal in equilibrium to the share of the foreign wage bill in the cost of ex-type composite labor. Hence, $\omega_{e x}^{N}:=\mathrm{d} \ln w_{e x}^{N} / d \ln L_{e x}^{M}=\left(s_{e x}^{M} / \sigma_{e}^{M}\right)+\zeta_{e x}^{p}$, where $\zeta_{e x}^{p}$ is the elasticity of $p_{e x}$ with respect to $L_{e x}^{M}$. We call $s_{e x}^{M} / \sigma_{e}^{M} \geq 0$ the partial elasticity of complementarity between native and foreign labor of type $e x$, partial meaning a constant levels of $L_{e x}^{N}$ and $p_{e x} .{ }^{8}$ While a finite value of $\sigma_{e}^{M}$ does install a force of native-immigrant-complementarity, this need not show up in general equilibrium across the board for all education and experience levels. To see the general equilibrium repercussions, we need to model the use of composite labor $L_{e x}$;

\footnotetext{
${ }^{7}$ It seems somewhat far-fetched to argue that foreign and native workers are imperfect substitutes by sheer ethnicity or nationality, all other relevant characteristics being the same. Borjas (2003) assumes that foreign and native workers are perfect substitutes; Aydemir and Borjas (2007) show that this assumption is met in US data. However, even for a high degree of disaggregation we must expect a certain amount of unobserved heterogeneity across native and foreign workers with the same observed education and experience. We therefore follow Ottaviano \& Peri (2006) in allowing imperfect substitutability and letting the data deliver the verdict. As in their case, our data suggest imperfect substitutability; see below. For an earlier treatment of this issue, see Grossman (1982).

${ }^{8}$ See Hamermesh (1993) who stresses that these partial elasticities hold for a constant goods price - in our case a constant shadow value of $L_{e x}$. Borjas (2003) considers elasticities similar to the ones derived below, but ignoring this bottom-level complementarity.
} 
see below.

How do we estimate the parameters of (1)? Allowing for cross-time variation, and dividing through by the conditional inverse demand for immigrant labor $L_{e x}^{M}$, we obtain an estimation equation of the form

$$
\ln \left(w_{t e x}^{N} / w_{t e x}^{M}\right)=-\frac{1}{\sigma_{e}^{M}} \ln \left(L_{t e x}^{N} / L_{t e x}^{M}\right)+d_{e x}+d_{e t}+d_{x t}+u_{t e x},
$$

where $u_{t e x}$ is a regular error term for time $t$. Throughout this paper, we use a time index $t$ when writing estimation equations. Following Ottaviano \& Peri (2005, 2006), we have replaced $\ln \left(\lambda_{t e x}^{N} / \lambda_{t e x}^{M}\right)$ by education $\times$ experience fixed effects $d_{e x}$, as well as education $\times$ time and experience $\times$ time fixed effects, $d_{e t}$ and $d_{x t}$, respectively. This restricts the variation of $\ln \lambda_{t e x}^{N} /\left[\left(1-\lambda_{t e x}^{N}\right)\right]$ to ensure identification of $\sigma_{e}^{M} \cdot{ }^{9}$ Writing $\hat{D}_{t e x}=\hat{d}_{e x}+$ $\hat{d}_{e t}+\hat{d}_{x t}$ for the sum of all fixed-effects-estimates, we can back out the share parameters as $\hat{\lambda}_{t e x}^{N}=\exp \left(\hat{D}_{t e x}\right)\left[1+\exp \left(\hat{D}_{t e x}\right)\right]^{-1}$. We also estimate education group specific $\sigma_{e}^{M}$ using $d_{x}$ instead of $D_{t e x}$. These estimates may be used, alongside $\hat{\sigma}_{e}^{M}$, to calculate an estimate of composite labor $\hat{L}_{t e x}$ according to (1), as well as an estimate of the minimum wage-cost $\hat{w}_{t e x}$ per unit of $L_{e x}$, based on the expenditure function $w_{e x}\left(w_{e x}^{N}, w_{e x}^{M}\right)$ dual to (1).

Composite labor of type $e x$ is further used in the domestic economy according to two further CES-nests. The first aggregates across different experience levels according to

$$
L_{e}=\left[\sum_{x \in \mathcal{X}} \lambda_{e x}\left(L_{e x}\right)^{\frac{\sigma^{x}-1}{\sigma x}}\right]^{\frac{\sigma^{x}}{\sigma^{x}-1}}
$$

where $\sigma^{x}$ denotes the elasticity of substitution across different experience levels, assumed to be constant for all educational attainments, and $\lambda_{e x}$ are share parameters. We normalize $\sum_{x \in \mathcal{X}} \lambda_{e x}=1$. Equating the wage for composite labor $L_{e x}$ with the marginal productivity, we obtain a conditional inverse labor demand function $w_{e x}=q_{e} \lambda_{e x}\left(L_{e} / L_{e x}\right)^{1 / \sigma^{x}}$, where $q_{e}$ is the shadow price of composite $e$-type labor $L_{e}$, in complete analogy to $p_{e x}$ above. We thus arrive at an estimation equation of the following form

$$
\ln w_{t e x}=-\frac{1}{\sigma^{x}} \ln L_{t e x}+d_{e x}+d_{e t}+d_{t}+\nu_{t e x},
$$

\footnotetext{
${ }^{9}$ Clearly, the vector $\ln \left(\lambda_{t e x}^{N} / \lambda_{t e x}^{M}\right)$ cannot be absorbed by period-education-experience fixed effects because we would have as many fixed effects as we have observations. With the restriction, we have a total number of observations of $T E X$ to estimate $E X+T E+T X$ fixed effects and $E$ elasticity values $\sigma_{e}^{M}$ ( $T$ being the number of time periods).
} 
where $\nu_{\text {tex }}$ again is an error term for time $t$. This is amenable to empirical estimation using the estimates $\hat{L}_{t e x}$ and $\hat{w}_{t e x}$ obtained in the first step to replace $w_{t e x}$ and $L_{t e x}$. By analogy to the preceding step, we have replaced $\ln q_{t e}+\frac{1}{\sigma^{x}} \ln L_{t e}+\ln \lambda_{t e x}$ by fixed effects, the identifying assumption being that $\lambda_{e x}$ is time-invariant. The term $\ln q_{e}+\frac{1}{\sigma^{x}} \ln L_{e}$ is thus represented by fixed effects $d_{e t}+d_{t}$. This picks up the effect of the $L_{e}$-employment levels on the marginal productivity of $L_{e x}$ for a given shadow-value of $L_{e}$, as well as the change of that value which follows from further use of $L_{e}$ in the economy; see below.

The link to native wages $w_{t e x}^{N}$ is given through the condition that $p_{e x}=w_{e x}$. This gives rise to an augmented view of native-immigrant complementarity, according to which $\omega_{e x}^{N}=s_{e x}^{M} / \sigma_{e}^{M}-s_{e x}^{M}\left(1-s_{e x}\right) / \sigma^{x}+\zeta_{e x}^{q}=s_{e x} s_{e x}^{M} / \sigma^{x}+s_{e x}^{M}\left(1 / \sigma_{e}^{M}-1 / \sigma^{x}\right)+\zeta_{e x}^{q}$, where $\zeta_{e x}^{q}$ stands for the elasticity of $q_{e}$ with respect to $L_{e x}^{M}$. A higher $L_{e x}^{M}$ affects $p_{e x}$ through a higher composite labor $L_{e x}$ according to $-s_{e x}^{M} / \sigma^{x}$, and through a higher employment $L_{e}$ according to $s_{e x}^{M} s_{e x} / \sigma^{x}$, conditional on $q_{e}$, the shadow-value of $L_{e}$ which is determined below. We may now also consider cross-experience effects. In particular, all workers with education $e$, but experience levels $x^{\prime} \neq x$ are effected through a change in 'their' $p_{e x^{\prime}}$ according to a cross-experience elasticity of complementarity $\xi_{e x}^{N}:=s_{e x}^{M} s_{e x} / \sigma^{x}+\zeta_{e x}^{q}$. Note that, due to the uniform elasticity of substitution $\sigma^{x}$, this is the same for all $x^{\prime} \neq x$ within $e$, for a given ex-type of labor inflow. Intuitively, old native engineers benefit from the arrival of young foreign engineers, with an elasticity of complementarity equal to $s_{e x}^{M} s_{e x} / \sigma^{x}>0$, conditional on $q_{e}$. If $\sigma^{x} / \sigma_{e}^{M}>1$, then we have the somewhat paradoxical result that $\omega_{e x}^{N}>\xi_{e x}^{N}$,meaning that native-migrant complementarity is even larger within the same experience level than across experience level. Intuitively, this is because young engineers are a better substitutes for more experienced engineers (native or foreign), than they are for foreign engineers with the same low experience. Moreover, if $\sigma^{x} / \sigma_{e}^{M}>$ $1-s_{e x}$, then $\omega_{e x}^{N}>0$, conditional on $q_{e}$. If $\sigma^{x} / \sigma_{e}^{M}<1-s_{e x}$, despite the element of complementarity introduced by $\sigma_{e}^{M}<\infty$, native $e x$-type workers are q-substitutes (in the sense of Hamermesh, 1993) for foreign workers.

Next, we endogenize $q_{e}$ from the marginal productivity of composite $e$-type labor. Recovering estimates for the share parameters $\hat{\lambda}_{e x}=\exp \left(d_{e x}\right)\left[\sum_{x} \exp \left(d_{e x}\right)\right]^{-1}$ and using the estimate $\hat{\sigma}^{x}$ we may calculate an estimate $\hat{L}_{t e}$ according to (3), as well as unit costs $\hat{w}_{t e}$ according to $w_{e}\left(w_{e 1}, \ldots, w_{e X}\right)$, the expenditure function dual to (3). In turn, these can then be used to estimate the parameters of

$$
L=\left[\sum_{e \in \mathcal{E}} \lambda_{e}\left(L_{e}\right)^{\frac{\sigma^{e}-1}{\sigma^{e}}}\right]^{\frac{\sigma^{e}}{\sigma^{e}-1}}
$$


which aggregates across all educational levels to arrive at a composite labor input $L_{e}$, with an elasticity of substitution $\sigma^{e}$ and share parameters $\lambda_{e}$, with $\Sigma_{e \in \mathcal{E}} \lambda_{e}=1$. By complete analogy to the above, we have a conditional inverse labor demand function $w_{e}=z \lambda_{e}\left(L / L_{e}\right)^{1 / \sigma^{e}}$, where $z$ denotes the shadow-value of composite labor $L$. Empirical estimation relies on

$$
\ln w_{t e}=-\frac{1}{\sigma^{e}} \ln L_{t e}+d_{t}+\delta_{e} t+v_{t e}
$$

where use the aforementioned estimates $\hat{w}_{t e}$ and $\hat{L}_{t e}$ in lieu of $w_{t e}$ and $L_{t e}$. Again, we have replaced $\ln z_{t}+\ln \lambda_{t e}+\frac{1}{\sigma^{e}} \ln L_{t}$ by fixed effects. The term $\ln z_{t}+\frac{1}{\sigma^{e}} \ln L_{t}$ is time varying, with an interpretation which follows by analogy from the preceding steps. The shadow-value $z_{t}$ has different interpretations. It may reflect overall output to be produced, as in Borjas (2003), or the aggregate capital to labor ratio which is governed by capital accumulation effects, as in Ottaviano \& Peri (2006). In the estimation it is picked up by time-fixed effects $d_{t}$. We further employ the identifying restriction that the parameters $\lambda_{t e}$ follow education-specific time trends, i.e., $\lambda_{t e}=\lambda_{0 e} \exp \left(\delta_{e} t\right)$.

Setting $q_{e}=w_{e}$ in our consideration of q-complementarity, we now have $\omega_{e x}^{N}=$ $s_{e x}^{M} / \sigma_{e}^{M}+\zeta_{e x}^{z}-s_{e x}^{M}\left(1-s_{e x}\right) / \sigma^{x}-s_{e x}^{M} s_{e x}\left(1-s_{e}\right) / \sigma^{e}$, where $s_{e}$ is the share of wage payments to $e$-type labor in the wage bill for $L$, and $\zeta_{e x}^{z}$ is the elasticity of $z$ with respect to $L_{e x}^{M}$. The term $s_{e x}^{M} s_{e x}\left(1-s_{e}\right) / \sigma^{e}$ is interpreted by complete analogy to the above, now looking at how an increase of $L_{e x}^{M}$ affects affects the marginal productivity of composite labor $L_{e}$. It is obvious that endogenizing upper-level shadow values of composite labor unambiguously reduces the algebraic value of the direct elasticity of complementarity, with the wage shares determining the exact point where it turns negative. There are now also cross-educational complementarity effects, whereby such an increase affects wages of native workers in educational branches $e^{\prime} \neq e$ through a change in 'their' $q_{e^{\prime}}$. The corresponding cross-education elasticity of complementarity is $\varepsilon_{e x}^{N}=s_{e x}^{M} s_{e x} s_{e} / \sigma^{e}+\zeta_{e x}^{z}$. Again, due to a uniform $\sigma^{e}$, these are the same for all $e^{\prime} \neq e$. Comparing the direct- and cross- elasticities of complementarity, we may rewrite $\omega_{e x}^{N}=s_{e x}^{M} s_{e x} s_{e} / \sigma^{e}+\zeta_{e x}^{z}+s_{e x}^{M} s_{e x}\left(1 / \sigma^{x}-1 / \sigma^{e}\right)+s_{e x}^{M}\left(1 / \sigma_{e}^{M}-1 / \sigma^{x}\right)$. If $\sigma_{e x}^{M}>\sigma^{x}>\sigma^{e}$, as in Borjas (2003) and Ottaviano \& Peri (2006), then $\omega_{e x}^{N}<\varepsilon_{e x}^{N}$, meaning that native workers with education $e$ are a closer q-substitute (in the sense of Hamermesh) for immigrants with the same education than native workers with different education. Indeed, conditional on $z$, immigrants across educational branches are always q-complements to native workers.

In order to endogenize $z$, we now assume a Cobb-Douglas production function for the 
final output good:

$$
Y(K, L)=A L^{1-\alpha} K^{\alpha} \quad \text { with } \quad \alpha \in[0,1] .
$$

This implies a unitary elasticity of substitution between $L$ and capital $K$, dispensing with the need of an estimation equation. Enforcing the equilibrium condition $w=z=$ $(1-\alpha) Y / L$ and assuming $Y$ is constant, as for instance in Borjas (2003), we have $\zeta_{e x}^{z}=-s_{e x}^{M} s_{e x} s_{e} s_{L}$, where $s_{L}$ denotes the overall wage share. The full general equilibrium values of the direct- and cross-elasticities of complementarity between natives and foreign workers become

$$
\begin{aligned}
\omega_{e x}^{N} & =s_{e x}^{M} s_{e x} s_{e}\left(1 / \sigma^{e}-1\right)+s_{e x}^{M} s_{e x}\left(1 / \sigma^{x}-1 / \sigma^{e}\right)+s_{e x}^{M}\left(1 / \sigma_{e}^{M}-1 / \sigma^{x}\right) ; \\
\xi_{e x}^{N} & =s_{e x}^{M} s_{e x} s_{e}\left(1 / \sigma^{e}-1\right)+s_{e x}^{M} s_{e x}\left(1 / \sigma^{x}-1 / \sigma^{e}\right) ; \\
\varepsilon_{e x}^{N} & =s_{e x}^{M} s_{e x} s_{e}\left(1 / \sigma^{e}-1\right) .
\end{aligned}
$$

Note that $\varepsilon_{e x}^{N}=s_{e x}^{M} s_{e x} s_{e}\left(1 / \sigma^{e}-1\right)>0$ provided that $\sigma^{e}>1$. Holding $Y$ constant (i.e., fixing an isoquant), the above elasticities may be interpreted as short-run elasticities. Alternatively, following Ottaviano \& Peri (2006), one may want to take a long-run perspective in assuming that endogenous capital accumulation ensures a constant marginal productivity of capital, and thus also of labor, in which case $\zeta_{e x}^{z}=0$ and $\varepsilon_{e x}^{N}=s_{e x}^{M} s_{e x} s_{e} / \sigma^{e}>0$. Notice also that $\omega_{e x}^{N}$ necessarily becomes negative if $\sigma_{e x}^{M} \rightarrow \infty$.

If a country considers selective immigration restrictions, and if native wage effects are the dominating magnitude in the policy goal, then the elasticities in (8) would be the key ingredient in any optimal policy calculus. Loosely speaking, policy would aim at high quotas in segments $e x$ where the complementarity effects, as for instance captured by $\varepsilon_{e x}^{N}$, are particularly high, acknowledging of course that the different elasticities in (8) are highly interdependent. The positive wage effects from a given immigration scenario for some types of native workers, as reported in particular in Ottaviano \& Peri (2006) stem from such complementarities. A country aimed at a liberal immigration policy might still be interested in compensating losers among the native labor force. Suppose that liberalization of given restrictions leads to an equiproportional inflow of foreign workers across all possible ex-types of labor. A one percent increase of $L_{e x}^{M}$, across the board, affects native workers of type $e^{\prime} x^{\prime}$ according to

$$
\kappa_{e^{\prime} x^{\prime}}^{N}=\omega_{e^{\prime} x^{\prime}}^{N}+\sum_{x \neq x^{\prime}} \xi_{e^{\prime} x}^{N}+\sum_{x \neq x^{\prime}} \sum_{e \neq e^{\prime}} \varepsilon_{e^{\prime} x^{\prime}}^{N}
$$

While the elasticities in (8) look at different types of foreign workers extending q-complementarity (or -substitutability) effects to native workers, elasticities $\kappa_{e^{\prime} x^{\prime}}^{N}$ look at different 
native workers receiving such effects from an equiproportional increase in foreign worker employment across all types of labor. We shall report both types of elasticities, based on our estimation results below. They provide a nicely structured way to present the whole system of empirical inverse labor demand functions of the economy - empirical analogues to the gradients $\tilde{\mathbf{L}}_{\mathbf{N}}^{N}$ and $\tilde{\mathbf{L}}_{\mathbf{M}}^{N}$ considered above.

The inverse labor demand functions for native workers that derive from this approach may be written in the following log-changes form, which takes a long-run perspective in assuming a constant marginal productivity of composite labor $L$ :

$$
\begin{aligned}
\mathrm{d} \ln w_{e x}^{N}= & \frac{1}{\sigma^{e}} \mathrm{~d} \ln L+\left(\frac{1}{\sigma^{x}}-\frac{1}{\sigma^{e}}\right) \mathrm{d} \ln L_{e} \\
& +\left(\frac{1}{\sigma^{M}}-\frac{1}{\sigma^{x}}\right) \mathrm{d} \ln L_{e x}-\frac{1}{\sigma^{M}} \mathrm{~d} \ln L_{e x}^{N}
\end{aligned}
$$

The corresponding log-change for the foreign wage $w_{e x}^{M} \operatorname{simply}$ replaces $\operatorname{dln} L_{e x}^{N}$ with $\operatorname{dln} L_{e x}^{M}$, and the various aggregate labor inputs are defined as above. Equations like this will be used in our simulation exercise, where changes in employment of (composite) labor on the right derive from the given immigration scenario, which implies changes in labor supply, and from the reduced form estimates that translate this into employment changes; see below.

\subsection{Endogeneity concerns}

Estimating the inverse labor demand functions as suggested above implies that we may treat employment changes as exogenous. This is legitimate if there is full employment throughout the entire sample period, and if all variation is driven by exogenous supply shifts that are themselves independent of the sample-variation in wages. Let us assume away unemployment for a moment. Then, any supply shift driven by changes in foreign workers should be fine, since a migrant's ex-characteristic is predetermined. ${ }^{10}$ However, while workers cannot choose their ex-characteristics at the time of migration, they can still choose the preferred destination country. This possibility is rarely discussed in the literature. Hence, ex-cells of the labor market where wages rise strongly over the sample may attract a relatively larger migrant inflow. Estimating (2) by OLS biases the estimate

\footnotetext{
${ }^{10}$ This is the main advantage of the Borjas-approach to earlier studies following the area-approach; see Borjas et al. (1996, 1997).
} 
of $\left|1 / \sigma_{M}\right|$ towards zero, thereby leading to overestimation of substitutability between natives and migrants. In the other specifications, we may essentially run into similar problems. However, in contrast to (2), we may run equations (4) or (6) on samples that exclude migrant workers, which should at least reduce the bias, or relying on instrumental variables techniques using native labor supply changes as instruments. ${ }^{11}$

A separate endogeneity concern follows from non-market-clearing labor market institutions. According to the LNJ-paradigm of European unemployment, the labor market adjusts to an equilibrium level of unemployment that simultaneously supports the real wage implicit in the price-setting behavior of firms, and the real wage implied by wagesetting. In very general terms, a country's goods and labor market institutions thus simultaneously determine its equilibrium real wage and rate of unemployment. This implies that the level of employment and the real wage are jointly determined by a country's institutions and labor supply. Thus, whatever the details of wage-setting, consistent estimation of our core parameters of labor demand may be guarded against this type of endogeneity by relying on labor supplies as instruments for employment. ${ }^{12}$ To the extent that labor supplies are indeed exogenous, this IV-strategy delivers unbiased estimates for substitution elasticities $\sigma_{e}^{M}, \sigma^{x}$ and $\sigma^{e}$ even in the presence of unemployment.

Another problem arises due to the fact that labor market institutions may reduce the variance of wages (and employment) over time and across cells. This makes inference more difficult, but does not, of course, invalidate estimation per se as long as some movement on firms' labor demand schedules does take place.

\subsection{Wage-setting and unemployment}

The elasticities of inverse labor demand derived above relate to employment changes, not changes in labor supply, which is what happens with immigration. We now use $M_{e x}$ and $N_{e x}$ to denote native and immigrant labor supply, respectively. With non-market-clearing labor market institutions we may not equate $\Delta M_{e x}=\Delta L_{e x}^{M}$ and $\Delta L_{e x}^{N}=0$, assuming that

\footnotetext{
${ }^{11}$ Migration-induced labor supply changes may also suffer from policy-induced endogeneity. If immigration restrictions are binding, and if they are designed to cater domestic labor market requirements, as often argued by policy makers, then any immigrant supply changes would be policy-induced and, thus, endogenous to wages.

${ }^{12}$ Brücker \& Jahn (2008) or D'Amuri et al. (2008) do not use instruments here.
} 
$\Delta N_{e x}=0$. We need a model that allows us to translate changes $\Delta M_{e x}$ from a 'realistic' immigration scenario into $\Delta L_{e x}^{M} \neq \Delta M_{e x}$ and $\Delta L_{e x}^{N} \neq 0$, allowing for unemployment in line with existing labor market institutions. These endogenous employment changes may then be inserted into the estimated inverse labor demand functions, in order to back out the general equilibrium wage effects from the immigration scenario, alongside displacement effects $\Delta L_{e x}^{N}<0$ and $\Delta L_{e x}^{M}-\Delta M_{e x}<0$.

In macroeconomic contexts, it has become customary to explain European unemployment through an interaction of price- and wage-setting; see Layard, Nickell \& Jackman (2005). Price-setting implies a relationship between price and marginal cost which is, in turn, dependent on the wage rate. Under reasonable conditions, marginal cost depends on employment, hence price setting implies a relationship between the real wage rate and employment. At the same time, labor market institutions are assumed to depart from market-clearing wage formation, such that the real wage rate depends on the rate of unemployment. Labor market equilibrium then implies a natural rate of unemployment which is consistent with both, price- and wage-setting. This framework is open to several specific interpretations. Indeed, as pointed out by Blanchard (2007), the set of interpretations even includes a conventional view of labor demand and supply, implying a zero natural rate of unemployment.

For the present purpose, we employ what Layard, Nickell \& Jackman (2005) have called "normal-cost price-setting". Assuming perfect competition on output markets, prices are equal to marginal cost, and the negative price-setting-relationship between the real wage rate and the rate of unemployment then derives from the presence of a fixed non-labor input like the capital stock. In our case, we thus arrive at several different price-setting relationships, coinciding with the inverse labor demand functions presented in the preceding section. More specifically, normalizing the output price to one, and given labor supplies for all types of labor, the level-version of equation (10) implies a relationship between the real wage rate for labor-type $e x$ and the rates of unemployment for all types of labor. A similar relationship may be derived for an environment where producers are faced with exogenous shocks to labor productivity and firing cost; see Angrist \& Kugler (2003). This introduces a wedge between the wage rate and the marginal value productivity of labor. Our entire story is unaffected by this type of labor market imperfection, provided that this wedge is constant.

Wage-setting, in turn, may be formulated through conventional upward-sloping labor supply schedules, as for instance in Angrist \& Kugler (2003) and D'Amuri et al. 
(2008). In terms of our notation, their approach implies an equation of the form $L_{e x}^{N}=$ $\left[w_{e x}^{N}(1-r)\right]^{\gamma} N_{e x}$ for native labor, and a corresponding expression for foreigners, with a uniform parameter $\gamma>0$ ). In this equation, $r$ denotes the replacement rate for unemployment benefits. Alternatively, and more in line with Layard, Nickell \& Jackman $(2005)^{13}$, the above equation might be written as

$$
w_{e x}^{N}=\bar{w}_{e x}^{N}\left(1-u_{e x}^{N}\right)^{1 / \gamma}(1-r)^{-1}
$$

and interpreted as a proper wage-setting equation. In this formulation, $\bar{w}_{e x}^{N}$ is a reference wage for wage-setting. ${ }^{14}$ In contrast to the conventional macroeconomic framework, this assumes that wage-setting takes place on a disaggregate-level, responding to the education-experience-related rates of unemployment for native labor $u_{e x}^{N}{ }^{15}$ Assuming a uniform $\eta$ across all educational and experience levels implies a uniform responsiveness of wage-setting behavior to changes in unemployment levels. This is a convenient identifying restriction, but it also makes sense for a country like Germany, with centralized labor market institutions. Depending on how foreign workers are covered by labor market institutions, a corresponding equation may or may not hold for foreign workers (with the same, or with a different parameters $\gamma$ ). In our empirical implementation, we allow for $\gamma$ to vary between native and foreign workers (denoted by $\gamma^{M}$ and $\gamma^{N}$, respectively).

Researchers have followed different strategies towards empirical implementation of this approach. Thus, Angrist \& Kugler estimate equations explaining the employmentto-population ratio ( $L^{N} / N$ in our notation) by the immigrant share in the labor force for different immigration countries and certain segments of their labor markets (female/male and age groups). ${ }^{16}$ These equations are reduced form relationships that follow from equating the wage rate from the inverse labor demand functions (price setting) with the wage rate from wage-setting. D'Amuri et al. (2008) follow a similar approach against the backdrop of an experience- and education-based nesting of labor demand. This then allows

\footnotetext{
${ }^{13}$ See also Blanchflower \& Oswald (2005).

${ }^{14}$ If this reference wage is set equal to the market clearing wage rate for $e x$-type labor, and if $r=0$, then the natural rate of unemployment is zero for all types of labor.

${ }^{15}$ In the macroeconomic context, wage setting normally relies on expected goods prices. The above formulation assumes perfect foresight, or a long-run equilibrium, where price expectations are borne out. Moreover, the output price is normalized to 1.

${ }^{16}$ Angrist \& Kugler (2003) do not follow the Borjas (2003) approach, but remain within the "areaapproach", treating different western European countries as "areas".
} 
them to augment equation (10) by induced employment changes for natives when using this equation in order to simulate wage effects from immigration. In their simulations for German immigration, D'Amuri et al. (2008) use estimates on German data only for $\sigma^{M}$, while relying on estimates for $\sigma^{x}$ and $\sigma^{e}$ obtained for the US. ${ }^{17}$

We follow a different approach in that all relevant elasticities of substitution are estimated on German data, and we use the same data set to also estimate the wage-setting parameter $\gamma$, which is then used for simulation. More specifically, our estimation equation for (11) for native workers is

$$
\ln w_{e x t}^{N}=\eta^{N} \ln \left(L_{e x t}^{N} / N_{e x t}\right)+\alpha \ln w_{e x t-1}^{N}+\kappa_{e x t}
$$

where $\kappa_{\text {ext }}$ is an error term. ${ }^{18}$ In this specification, $\eta^{N}=1 / \gamma^{N}$ which we expect to be positive from theory. The lagged wage is added to allow for lagged adjustment, with a long-run elasticity of $\eta^{N} /(1-\alpha)$. Not shown in (12), we also take into account educationspecific time trends and squared education-specific time trends, to take into account exogenous long-run changes in reference wages $\bar{w}_{e x}^{N}$ in (11).

For a better understanding of our simulation results below, we briefly look at the wage and employment effects of a certain immigration $\mathrm{d} M_{e x}$, assuming zero immigration for all other types of labor, and assuming $\mathrm{d} N_{e x}=0$ throughout. Returning to the elasticities of q-complementarity in (8a) above, it is relatively straightforward that $\omega_{e x}^{M}:=\omega_{e x}^{N} s_{e x}^{M} / s_{e x}^{N}$ is the elasticity of complementarity between foreign and native labor, where $\omega_{e x}^{N}$ captures the reverse complementarity between native and foreign labor, as given in (8a). By analogy we have $\tilde{\omega}_{e x}^{N}:=\omega_{e x}^{N} s_{e x}^{N} / s_{e x}^{M}-1 / \sigma^{M}<0$ as the direct elasticity of native wages with respect to native employment, and $\tilde{\omega}_{e x}^{M}:=\omega_{e x}^{M} s_{e x}^{M} / s_{e x}^{N}-1 / \sigma^{M}<0$ for the corresponding elasticity of wages for foreigners. ${ }^{19}$ With these definitions, we may use equation (10) above to write $\mathrm{d} \ln w_{e x}^{N}=\tilde{\omega}_{e x}^{N} \mathrm{~d} \ln L_{e x}^{N}+\omega_{e x}^{N} \mathrm{~d} \ln L_{e x}^{M}$, and $\operatorname{d} \ln w_{e x}^{M}=\tilde{\omega}_{e x}^{M} \mathrm{~d} \ln L_{e x}^{M}+\omega_{e x}^{M} \mathrm{~d} \ln L_{e x}^{N}$ (note that $\omega$ are cross-elasticities). Assuming constant institutional variables $\bar{w}_{e x}^{N}, \bar{w}_{e x}^{M}, r^{N}$ and $r^{M}$ and a

\footnotetext{
${ }^{17}$ In addition to the nesting introduced above, D'Amuri et al. (2008) allow for imperfect substitutability between old and new immigrants. However, their data suggest a close to infinity elasticity of substitution on this lowest level.

${ }^{18}$ In the relevant table below, we also report estimates for an alternative equation with the unemployment rate replacing $\ln \left(L_{e x t}^{N} / N_{e x t}\right)$. Equation (12) allows for a more convenient formulation of numerical simulation below.

${ }^{19}$ The sign of the own-elasticities, $\tilde{\omega}_{e x}^{N}<0$ and $\tilde{\omega}_{e x}^{M}<0$, follows from concavity of the production function; see Hamermesh (1993).
} 
constant native labor force, wage-setting implies $\operatorname{dln} w_{e x}^{N}=\eta^{N} \operatorname{dln} L_{e x}^{N}$, as well as $\operatorname{dln} w_{e x}^{M}=$ $\eta^{M} \mathrm{~d} \ln L_{e x}^{M}$. These four equations determine equilibrium reactions of wages and employment for natives and foreigners. For the simpler case where wage-setting is restricted to native labor (Walrasian labor markets for immigrants) we have $\operatorname{d} \ln L_{e x}^{M}=\operatorname{dln} M_{e x}$, and the native wage effect is equal to $\operatorname{dln} w_{e x}^{N}=\left[\omega_{e x}^{N} /\left(1-\tilde{\omega}_{e x}^{N} / \eta^{N}\right)\right] \operatorname{dln} M_{e x}$. Since $\tilde{\omega}_{e x}^{N} / \eta^{N}<0$ and $\left(1-\tilde{\omega}_{e x}^{N} / \eta^{N}\right)>1$, wage-setting moderates the partial equilibrium wage effects of immigration, relative to the reference case of Walrasian labor markets where $\mathrm{d} \ln w_{e x}^{N}=\omega_{e x}^{N} \mathrm{~d} \ln M_{e x}$. Inserting back into the wage-setting equation, the native employment effect emerges as $\operatorname{dln} L_{e x}^{N}=\left[\omega_{e x}^{N} /\left(\eta^{N}-\tilde{\omega}_{e x}^{N}\right)\right] \operatorname{dln} M_{e x}$. Note that $\eta^{N}-\tilde{\omega}_{e x}^{N}>0$. Hence, native employment of $e x$-type workers rises, if there is q-complementarity between natives and foreigners, $\omega_{e x}^{N}>0$, and vice versa; see also Angrist \& Kugler (2003). The intuition is that q-complementarity implies a rise in the marginal productivity of native labor at the initial level of native employment. For a rise in native wages to be consistent with the wage-setting constraint, there must be an offsetting increase in employment (lower unemployment). This, in turn, moderates the wage effect, relative to the Walrasian case. If there is q-substitutability, by the same argument there must be a fall in employment, leading to a less severe wage cut than would obtain in the Walrasian case. In our simulation below, we have a system of $E \times X$ estimated inverse labor demand equations for natives (including all cross-effects from education experience and natives), plus corresponding equations for foreigners. In addition, we have $E \times X$ estimated wage curves for natives as well as for foreigners. This, of course, generates a complex pattern of interactions which is amenable to solution only via numerical methods. The results give us employment (or unemployment) as well as wage effects, which reported below.

\section{Data}

In order to implement the empirical strategy discussed in section 2, we require micro-level data on individuals' wage rates and labor market status (employed, unemployed, out of labor force) as well as characteristics such as the education, work experience, and whether he or she is a migrant or a native. Typically, researchers draw on census data (Borjas, 2003; Ottaviano \& Peri, 2005, 2006; Aydemir and Borjas, 2007), or social security data (Bonin, 2005; Brücker \& Jahn, 2007). We use the German Socio-Economic Panel (SOEP) to obtain information about wages. We use the German micro-census for reliable data on the size and time evolution of our education-experience-place of birth labor market 
cells. ${ }^{20}$ We do have social security data for Germany (the IABS database), but this data set has a number of important short-comings.

The SOEP, published by the DIW, Berlin ${ }^{21}$ is a large longitudinal panel data set with a wide range of personal, household and family specific micro-data, collected by faceto-face interviews with all family members over 16 years, and covering natives as well as foreigners/immigrants. Interviews have been repeated annually, starting in 1984, with sample refreshment or extensions taking place in 1990, 1994-95, 1998, 2000, 2002 and 2006. The DIW generates year-specific weights for certain individual characteristics, based on micro-census data, which allow us to treat data between sample refreshments/extensions as being representative for the entire German population (including new states after unification). The sample size is relatively small, including about 12,000 households and 20.000 persons, but the SOEP data set offers a number of unique advantages.

First, the SOEP allows to define as immigrants individuals born outside of Germany. Official German data or social security data usually uses nationality as a criterion to distinguish natives and immigrants. In that case, the status of individuals depends on the volatile nature of naturalization policy. ${ }^{22}$ Moreover, successful naturalization depends also on the efforts of immigrants and, hence, may be endogenous, while the foreign-born criterion is clearly exogenous.

Second, the SOEP provides information about education of individuals in line with the International Standard Classification of Education adopted by the UNESCO in 1997 (ISCED-97). This classification allows to deal with the peculiarities of the German education system, e.g., the role of the apprenticeship system. Other data bases measure education by years of schooling, which makes meaningful comparisons across countries

\footnotetext{
${ }^{20}$ The micro-census does not provide data on wages. Manacorda et al. (2006) use a similar strategy in their study for for UK, combining the Labour Force Survey (LFS) and the General Household Survey (GHS)).

${ }^{21}$ See http://www.diw.de/english/sop/index.html for details.

${ }^{22}$ Official German statistics (and the IABS) define migrants according to citizenship (ius sanguis principle). Traditionally, naturalization rates have been extremely low in Germany, so that children of immigrants often do not have the German citizenship. Moreover, the naturalization law has changed drastically in 1999. On the other hand, after the collapse of the Soviet Union, almost two million ethnic Germans migrated to Germany and - according to ius sanguis rules - immediately qualified for German citizenship.
} 
with different education systems difficult. ${ }^{23}$

Third, the SOEP directly reports the experience of workers and even differentiates between experience earned in full-time and part-time jobs. This is a unique advantage compared to US census data or the IABS, where experience needs to be approximated by time elapsed since an individual has left school. This measure is obviously distorted by possible unemployment spells or maternity leaves, so that the literature (e.g., Borjas, 2003) uses only male workers.

Fourth, and most importantly, the SOEP reports gross wages on an monthly basis without any censoring. Using information on working hours per week, we calculate hourly wages. Data based on social security records (e.g., the IABS) do not provide information on wages for workers with wages below or above some (time-moving) threshold and require substantial imputation.

We cluster workers into different education and experience groups. Recall that the number of observations available for our regressions directly depends on the number of those groups $(N=T \times X \times E)$, so that a finer classification grid drives up the sample size. However, the larger $X$ or $E$ become, the smaller the number of observations (in particular those for migrants) in each cell. Hence, the definition of education-experience cells requires to trade-off cell-specific sample sizes against the number of observations available to run our regressions. Having data from 1984-2005, and setting $X=E=4$, we have a perfectly balanced sample of 352 observations (704 when differentiating between migrants and natives).

The four education groups are defined as follows: ISCED-levels 0 through 2 (lower secondary education or second stage of basic education), ISCED-level 3 (upper secondary education), ISCED-levels 4 and 5 (post-secondary up to first stage tertiary education), and ISCED-level 6 (second stage tertiary education). Regarding experience, we take the sum of observed full-time and part-time experience and use four categories, each covering a span of 10 years, up to a maximum of 40 years.

\footnotetext{
${ }^{23}$ For example, the French high school system allows for professional education (the Bac-pro); individuals enrolled in this system are treated as students. In Germany, a similar educational aim is achieved outside the high school system through the apprenticeship scheme (or dual education system). If education is measured by years of schooling, the two systems would assign different values to a student who achieves the same objective.
} 
Our time span goes back beyond German unification in 1990. Therefore, we restrict our observations to the western part of Germany, but treat persons born in the eastern part as German natives. This implies that around unification internal migration from the eastern to the western part of Germany provides a truly exogenous, experiment-like variation of labor supply across experience levels and educational groups.

Table 1 in the Appendix provides descriptive statistics of our data set. Over the years, the average cell size for the computation of wage or unemployment averages is 76 for migrants and 194 for natives. Some cells typically have only very few observations, in particular those for migrants with high education and experience levels in early years of our study. This is despite the over-sampling of migrants used by the SOEP and constitutes a disadvantage of our data. However, since the SOEP is matched to micro-census data, cell sizes and their time variance are representative. On average over 1984-2005, in Western Germany, there are about 28.4 million full-time employed workers; 3.8 million thereof are migrants (defined as foreign-born and/or with foreign nationality). The last column of the table reports the total change from 1984 to 2004 of the cell-sizes as reported in the micro census. Clearly, there is a large amount of time variation for both the immigrant and the native populations. This variation allows identification of our parameters of interest.

\section{Estimation and Simulation Results}

We first present estimates of the key labor demand parameters, as well as estimates of the reduced form which incorporates non-Walrasian wage-setting and unemployment. We also depict a detailed picture of q-complementarity and substitutability between native and foreign workers. Subsequently, we introduce a 'realistic' counterfactual scenario of German immigration and use our parameter estimates to calculate the pains and gains that Germany has foregone by opting for immigration restrictions through the transitional agreements in the recent eastern enlargement of the EU.

Table 2 presents estimates of the various elasticities of substitution that govern labor demand. Our baseline specification accounts for endogeneity by instrumenting labor demand by labor supply. The remaining columns contain robustness checks. Rows 1 through 5 address the elasticity of substitution between natives and migrants. For the baseline specification we find $1 / \hat{\sigma}^{M}=0.136$ with a robust standard error of 0.04 , which implies an elasticity value of 7.4. Rows 2 through 5 allow for education-specific elas- 
ticities $\hat{\sigma}_{e}^{M}$, revealing some variation across educational branches. ${ }^{24}$ The elasticity $\sigma^{M}$ importantly determines how an economy absorbs immigration. For instance, a relatively low estimated value of $\sigma^{M}$ drives the complementarity effects behind the native wage increases calculated by Ottaviano \& Peri (2006). Arguing for a different slicing of the labor market, Borjas \& Hanson (2008) question $\sigma^{M}$-estimates below infinity for the US. Our estimates in table 2 do indicate that natives and migrants are somewhat closer substitutes for each other in Germany than in the US or the UK [see Manacorda et al. (2006)], but with an elasticity of substitution well below infinity. This is in line with the results of Brücker \& Jahn (2008) and D'Amuri et al. (2008) who also find larger elasticities. We interpret this as indicating a certain degree of unobserved heterogeneity across native and foreign workers even within a given ex-cell. By and large, our finding of a fairly large, yet finite elasticity of substitution $\hat{\sigma}^{M}$ survives the robustness checks reported in table 2. This also holds true for the pattern of heterogeneity across educational groups, with the exception of an alternative definition of migrant status (column 7) which we know to be less appropriate a priori; see above.

Line 6 turns to $1 / \sigma^{x}$, the elasticity of substitution across experience levels. Our estimates are not statistically distinguishable from zero, hence we are unable to reject the hypothesis of $\sigma^{x} \rightarrow \infty$. US studies have found much lower values of this elasticity, also well below the estimates for $\sigma^{M}$, as perhaps expected from intuition ${ }^{25}$ A value of $\sigma^{x}>\sigma^{M}$ has important implications on the pattern of complementarity which we shall highlight below. Manacorda et al. obtain $\hat{\sigma}^{x}>\hat{\sigma}_{e}^{M}$ for the UK, as we do for Germany, but with an estimated value for $\sigma^{x}$ which is clearly much smaller than infinity. Large estimates for $\sigma^{x}$ (in the vicinity of 30) have also been found by Brücker \& Jahn (2008) who use German social security data. Both the magnitudes and the rank order of the estimated elasticities indicate that Germany and the US are different in how immigration is absorbed in the labor market. In our framework the difference must be interpreted as a difference in technology which, in turn, may reflect different patterns of specialization, as

\footnotetext{
${ }^{24}$ In particular, the top level of education (ISCED 6) exhibits an elasticity in the vicinity of 4 , while for lower level of education the elasticity is in the vicinity of 10 . The large difference between the elasticities for ISCED $4+5$ and ISCED 6 and the insignificant estimate for ISCED $4+5$ are probably due to the fact that ISCED $4+5$ mainly contains degrees that are specific to the German educational system. This means that most foreigners in this group have been educated in Germany.

${ }^{25}$ Borjas assumes $\sigma^{M} \rightarrow \infty$, and he estimates values $\sigma^{x}=3.5$ and $\sigma^{e}=1.3$, while Ottaviano \& Peri estimates $\sigma^{M}$-values between 5 and 10, $\sigma^{e}$ values between 3 and 5 , and $\sigma^{e}$-values around 2 .
} 
well as deep-lying differences in the educational system and other institutional features. A higher $\sigma^{x}$-value for Germany than the US is also consistent with the empirical observation of relatively large German unemployment among older people. In our numerical simulation below, we shall set $\sigma^{x}=100$, which is consistent with our estimation result, while retaining computability of the model. It should be noted that an infinite value of $\sigma^{x}$ is perfectly consistent with more experienced workers being more productive (in a Harrod-neutral sense) than less experienced ones, thus also receiving higher wages. It is also worth mentioning that D'Amuri et al. (2008), in their simulations for Germany, do not use a $\sigma^{x}$-elasticity value estimated on German data, but use the estimates from Ottaviano and Peri (2006) for the USA. ${ }^{26}$

Concerning the elasticity of substitution across educational groups, our baseline estimate is $1 / \hat{\sigma}^{e}=0.218$, with a standard error of 0.047 . Hence, $\hat{\sigma}^{e}$ is approximately equal to 4.6, which is somewhat larger than the estimates reported by Borjas (2003), Ottaviano \& Peri (2006) and Aydemir \& Borjas (2007), but in line with estimates obtained by Brücker \& Jahn (2008) for Germany. As with $\sigma^{x}$, D'Amuri et al. (2008) use US-estimates in their simulation for Germany. Our robustness checks in columns (2) to (7) of table 2 point towards a fairly consistent picture, with $\hat{\sigma}^{e}=4.6$ a reasonable middle ground.

Overall, then, the different types of labor considered here for the German economy feature a larger degree of substitutability in production than was found for a similar disaggregation of the US and UK labor markets. Note that our empirical strategy is consistent also with non-Walrasian labor market features, as already emphasized above. Hence, our estimated elasticities of substitution reflect the technological environment. This will be combined with the institutional feature of wage-setting below. The finding of large elasticities is interesting and has wide-reaching implications beyond the effects of immigration. We relegate the analysis of the causes of the cross-country differences to future work.

What do the estimated elasticities imply in terms of complementarity between German and foreign workers? We may use the estimates to construct the various elasticities of q-complementarity (8) that we have introduced in section 2 above. They are presented in table 3. In order to make our numbers comparable to those of Borjas (2003), we re-define

\footnotetext{
${ }^{26}$ Our results suggest that using US estimates is problematic, since elasticities of substitution appear substantially larger in Germany than in the US. Brücker \& Jahn (2008) find a similar result.
} 
the elasticities so that they relate to percentage employment changes in composite $e x-$ type labor $L_{e x}$, instead of percentage changes in $L_{e x}^{M}$. I.e., we divide all elasticities defined in (8) above through $s_{e x}^{M}$. The policy interpretation of these elasticities is as follows. Within columns 1 through 3 , a row-wise reading of Table 3 would give useful information for a policy maker who aims at a maximum degree of q-complementarity in designing an immigration quota system based on educational attainment and experience of foreign workers. The elasticities depict the q-complementarity that immigrants with different $e x-$ characteristics would extend to natives with the same characteristics, as well as natives with different experience levels and natives with different educational attainments. In all cases q-complementarity is measured as the percentage increase in native wages $w_{e x}^{N}$ relative to a 1 percent increase in employment of composite labor $L_{e x}$.

Notice that the direct elasticities reported in Table 3 are much lower in absolute value than in Borjas (2003), indeed even positive in a number of cases. The reason is a direct complementarity that arises from imperfect substitution between foreign and native workers within any one $e x$-group. Notice also that there is less complementarity across experience levels than within the corresponding $e x$-branch, which reflects the rank order of our estimated elasticities. ${ }^{27}$ By way of example, a migration-induced 10 percent increase in $L_{e x}$ for $e=1$ (ISCED 1-2 ) and $x=1$ ( 0 - 10 years) depresses wages of natives with $e=1$ but $x \neq 1$ by 0.18 percent. Analogous interpretations hold for elasticities across educational attainments (column 3). The final column of Table 3 takes a different perspective in looking at how much q-complementarity native workers with different $e x$ characteristics would receive from an equiproportional inflow of foreign workers across all $e x$-cells of the labor market. It indicates, for instance, that a uniform 10 percent increase in $L_{e x}$ brought about by immigration depresses wages of native workers with $e=1$ and $x=1$ by 0.94 percent, while native workers with $e=3$ (ISCED $4-5)$ and $x=4(\geq 31$ years) would face a 0.86 percent wage cut.

Table 4 takes us one step further towards a simulation exercise by reporting estimated parameters of equation (12) which represents wage-setting. For easier comparison with

\footnotetext{
${ }^{27}$ The direct elasticity of q-complementarity is defined as $\omega_{e x}^{N}=s_{e x}^{M} s_{e x} s_{e}\left(1 / \sigma^{e}-1\right)+s_{e x}^{M} s_{e x}\left(1 / \sigma^{x}-\right.$ $\left.1 / \sigma^{e}\right)+s_{e x}^{M}\left(1 / \sigma_{e}^{M}-1 / \sigma^{x}\right)$. Our rank-order for the elasticities of substitution is $\sigma^{x}>\sigma_{e}^{M}>\sigma^{e}>1$, which explains the somewhat counter-intuitive result that $\omega_{e x}^{N}$ is positive for some ex, and consistently higher in algebraic terms than the cross-experience elasticity $\xi_{e x}^{N}=s_{e x}^{M} s_{e x} s_{e}\left(1 / \sigma^{e}-1\right)+s_{e x}^{M} s_{e x}\left(1 / \sigma^{x}-1 / \sigma^{e}\right)$, while for an analogous reason $\varepsilon_{e x}^{N}=s_{e x}^{M} s_{e x} s_{e}\left(1 / \sigma^{e}-1\right)$ is consistently lower than $\xi_{e x}^{N}$.
} 
the literature, we have also run estimations on the unemployment rate instead of the log employment ratio. We report short-run estimates obtained including a lagged dependent variable, and long-run estimates $\eta /(1-\alpha)$. Our baseline uses pooled regression, where we estimate an $\eta$-value of 0.08 in the short-run, and a long-run value of 0.55 in the long-run. Comparing with Brücker \& Jahn (2008), who use individual-specific effects, we estimate a somewhat larger sensitivity of wage-setting with respect to unemployment. Our robustness checks in table 4 reveal that individual-specific effects using ArellanoBond an conventional fixed effects reveals estimates that are broadly in line Brücker \& Jahn (2008).

We can now enter a simulation experiment. Our scenario is motivated by the recent eastern enlargement of the EU where Germany, along with all other incumbent countries except the UK, Sweden and Ireland, has opted for keeping its bilateral import restrictions on migration from new member countries, as provided for by the so-called transitional agreements. It is well known that the migration flow from new member countries to the UK has turned out to be larger than expected prior to the enlargement in 2004. The guiding assumption for our first scenario is that without the transitional agreement the German economy would have received the flows that have now ended up in the UK. This is, of course, a rough 'guesstimate', but it serves our purpose well. It is probably a lower bound for the counterfactual of enlargement without a German transitional agreement on immigration. Using British Labour force surveys (LFS) for the forth quarters of 2003 and 2006, we have calculated the skill distribution of the immigrant labor force from the new EU member states in the UK. The ISCED levels are derived according to the LFS Users Guide (2006). The distinction between ISCED 5 and 6 differs from the one in the GSOEP. As ISCED $4+5$ are mainly specific German degrees, we assume that all persons with ISCED 4-6 have ISCED 6. Experience is calculated as age-16 for ISCED 0-2, age-19 for ISCED 3 and age-22 for ISCED 4-6. Moreover, we replace negative changes in the highest experience group by zero, as this probably reflects a mere cohort effect. Overall, we calculate an increase in the labor force by about 290,000 people. Details are found in table 5 .

We also construct an upper bound scenario for immigration from new EU member states. Sinn et al. (2001) estimate an overall German immigration potential from new EU members equal 4 mio people. ${ }^{28}$ This number is about 12 times larger than the migration

\footnotetext{
${ }^{28}$ See Zaiceva (2006) for an overview of various estimates of the migration potential from new EU
} 
flow from new member states into the UK in the last years. Hence, our upper-bound scenario scales up the lower bound by a factor of 12 . The difference between the lower and upper bound may seem disturbingly large, but it is still a useful exercise. Moreover, it is plausible that the composition of migrants would have been more strongly biased towards individuals with low education and experience levels, if the migrant flow had approached the upper bound. Table 5 presents the end-of-sample (2004) numbers and shares of foreign workers in the $16 \mathrm{ex}$-cells of the German labor market, as well as the increase in foreign workers according to our counterfactual scenarios. The increases are expressed in absolute numbers, as well as in percentage increases of $M_{e x}$ and $\left(M_{e x}+N_{e x}\right)$, respectively.

Tables 6 and 7 present simulation results for the case where we use education-specific elasticities $\sigma_{e}^{M}$. Summarizing table 6 , which depicts the lower-bound immigration scenario, we may state the following. First, looking at the reference case of perfect labor markets, we do not detect an aggregate complementarity effect for natives, although wage cuts are moderate. The brunt of adjustment lies with pre-existing immigrants, but this is ameliorated through capital accumulation, which even turns wage cuts into long-run gains for natives. Allowing for unemployment due to wage-setting, we observe a different pattern. Note that our numerical solution is based on the pooled OLS estimates for the wage elasticity $\eta$ reported in table 4 . In the short-run, foreigners effectively receive substantial wage protection, but this comes at the expense of employment, with more than half the inflow initially unemployed. In the long-run, with a higher estimated elasticity value for $\eta$, migrants effectively lose much of this protection. Lost wage protection overcompensates the complementarity effect from capital accumulation, with only a moderate unemployment effect remaining in the long-run, coupled with a stronger wage cut. In other words, short-run wage protection leads to a large deviation from the reference case of perfect labor markets, whereas in the long-run, with a higher wage-elasticity $\eta$, the wage-setting equilibrium approaches the full employment equilibrium. The full employment equilibrium features a lower wage cut for the long-run than the short-run, as expected. With wage setting, however, the short-run equilibrium features a protective effect from wage-setting, which is particularly strong for foreigners. Indeed, it makes the short-run equilibrium look more attractive to immigrants than the long-run equilibrium, which features the benefit of capital accumulation, but also the partial loss of wage pro-

member states. 
tection. For natives, lost wage protection applies in the long-run as well, but in a modified way. For perfect labor markets, capital accumulation turns the native wage cut to a longrun wage increase. Wage-setting then implies higher employment and lower wages than would be the case with a perfect labor market. But unlike foreigners, natives still find a more favorable effect of immigration in the the long-run than in the short-run.

Not surprisingly, our upper bound scenario delivers much higher numbers, as evidenced by table 7 . Immigration now amounts to an increase in the German workforce by as much as 10 percent (table 5). This is comparable to the scenarios considered by Borjas (2003) or Ottaviano and Peri (2006), who simulate an 11 percent increase in the US labor force. Importantly, we find that increasing the magnitude of the shock does not overturn the qualitative pattern of our results. Thus, unlike Felbermayr \& Kohler (2007), we find wage adjustment to be monotonic in the magnitude of foreign labor inflow. For the upper-bound scenario as well, our results suggest that pre-existing immigrants have to bear the main brunt of adjustment. In the short-run, their unemployment rate increases by about 19 percentage points. In the long-run, with the domestic capital stock adjusting to keep the marginal productivity of overall labor $L$ constant, it is still 3.4 percentage points above the initial level. Moreover, immigrant wages fall by 3.3 percent in the short-run, and by 5.8 percent in the long-run, due to a lower degree of wage protection received from wagesetting. In the short-run, the average native suffers a 0.2 percent wage cut, which is turned into a 0.6 wage gain in the long-run. For natives too, the short-run effect features a higher rate of unemployment, increasing by 1.7 percentage points for the average native, and by 2.0 percentage points for low-skilled natives. However, the long-run perspective looks much brighter, with unemployment going down by 1 percentage point for the average native worker. Thus, for natives the complementarity gain from capital accumulation dominats the partial loss of wage protection.

Table 8 repeats the simulation exercise, now assuming a uniform value of 7.4 for the elasticity between natives and foreigners, instead of education-specific $\sigma_{e}^{M}$-values. The simulation results do not change in any important way, except perhaps for the fact that the negative effects on low-skilled workers are now clearly stronger, and the ones for high skilled workers are somewhat weaker.

The wage and unemployment effects from this immigration counterfactual may be seen as the pains that the German economy was spared through opting for transitional immigration restrictions in eastern EU enlargement. What, then, are the gains forgone? Our simulation results enable us to also calculate the welfare effects from the counterfac- 
tual immigration scenario. In section 2 above, we have argued that with perfect labor markets the welfare effects for native labor may be approximated by $\mathbf{N}^{T} \mathrm{~d} \mathbf{w}^{N}$, where vectors $\mathbf{N}$ and $\mathbf{w}^{N}$ denote native labor supply and wages, respectively, for our 16 different types of education and experience levels ( $T$ indicating vector transposition). With labor market imperfections leading to changes in native employment, the welfare effect for native labor must look at employment in addition to wages, and it generalizes to $\left(\mathbf{L}^{N}\right)^{T} \mathrm{~d} \mathbf{w}^{N}+\left(\mathbf{w}^{N}\right)^{T} \mathrm{~d} \mathbf{L}^{N}$. For the pre-existing stock of foreign workers the effect is $\left(\mathbf{L}^{M}\right)^{T} \mathrm{~d} \mathbf{w}^{M}+\left(\mathbf{w}^{M}\right)^{T}\left(\mathrm{~d} \tilde{\mathbf{L}}^{M}-\mathrm{d} \tilde{\mathbf{M}}\right)$, where $\mathrm{d} \tilde{\mathbf{L}}^{M}$ denotes the general equilibrium effect of immigration on employment of pre-existing foreign workers. Table 9 depicts the results for the wage-setting case with unemployment for both, the lower-bound-scenario and the upper-bound scenario. We add the percentage effect on capital income to complete the picture. In the short-run both, natives and foreigners, have to suffer a welfare loss. In the long-run natives gain from immigration and this welfare gain outweighs the welfare loss of former immigrated foreigners. As expected the effects are much larger for the upper-bound scenario than the lower-bound one. Gains for capital owners are calculated according to $(1-\alpha)$ dln $L$, from the Cobb-Douglas marginal productivity condition. This is a lower bound, because it ignores the triangular gain deriving from capital accumulation. At the same time, however, it ignores discounting which works in the other direction. The negative short-run effect for natives seems to negate the familiar immigration surplus. However, as we have shown in Felbermayr \& Kohler (2007), with pre-existing foreign labor, this surplus may be negative. This case obtains in the short-, but not in the long-run. In addition, these results are based on a non-labor-market-clearing adjustment through wage-setting, as opposed to the neoclassical case underlying the immigration surplus.

\section{Conclusions}

There is much controversy about immigration policy, in Germany and elsewhere. This reflects different views and interests, but it also reflects a considerable amount of uncertainty about the effects of immigration. Any increase in the domestic labor force should, other things equal, exert a downward pressure on domestic wages. However, with well functioning labor markets, it should at the same time increase welfare of natives as a whole. But with labor market imperfections, there might also be a rise in unemployment. Fear of unwelcome wage and employment effects leads many countries to run highly restrictive immigration policies. It has also lead the majority of EU countries to 
opt for maintaining restrictions on immigration vis a vis new member countries under the so-called transitional arrangement.

Germany was among the countries taking a restrictive stance on migration from new member countries, invoking the transitional arrangement agreed upon in the negotiations leading up to eastern enlargement in 2004. At the time, uncertainty about the effects of immigration as such was aggravated by uncertainty about the likely size and composition of the labor inflow that would follow from implementing the single-market-freedom of labor migration. In this paper, we have attempted to fill this void, proceeding in three steps. First, we have estimated a structural model of labor demand focusing on worker experience and education. Our model is borrowed from Borjas (2003). Following Ottaviano \& Peri (2006) and Manacorda et al. (2006) we allow for imperfect substitution between foreign and native workers with the same level of experience and education. Unlike these other studies, however, we allowed for unemployment. In particular, we embed our structural view of labor demand in a price-wage-setting framework of the type proposed by Layard, Nickell \& Jackman (2005) to understand European unemployment. We estimate a suitably specified wage-setting equation, which then allows us to establish disaggregate relationships between changes in labor supply and changes in employment. In the third step, we rely on observed migration into the UK, in order to construct a counterfactual "free-movement scenario" of EU enlargement for Germany, and we use our econometric estimates for labor demand parameters and the estimated wage-setting equation, in order to simulate the wage and employment effects of this counterfactual.

Our econometric results suggest that, even for a fairly fine grid of education and experience levels, natives and foreigners are imperfect substitutes in German labor demand. The estimated elasticity of substitution varies somewhat across educational levels, but the majority of estimated elasticity values are below 10. Workers with different experience levels, however, are revealed to be almost perfect substitutes. This is a particular aspect where our results differ vastly from those for other countries, but they are in line with other evidence for Germany. Our estimate for the elasticity of substitution across different educational attainments is in the vicinity of 4 , which is also somewhat larger than the estimates found for other countries, but significantly lower than the elasticity of substitution between German natives and foreigners. These elasticity values imply a particular pattern of complementarity between migrants and German native workers, both within and across educational and experience groups. While imperfect substitutability between natives and foreigners generally favors complementarity, higher elasticities of substitution 
across experience and educational groups tend to work in the opposite direction for a given immigration scenario.

Combining these elasticity estimates with the wage-setting estimates allows us to see what all of this implies for a particular immigration scenario. We address a scenario which is motivated by the recent eastern enlargement of the EU. It basically assumes that, absent transitional restrictions, Germany would have attracted immigration from new member countries comparable in size and composition to the inflow observed for the UK. This gives us a 6 percent increase in the total migrant work force for Germany, which we treat as a lower-bound-scenario. Scaling-up this scenario in line with extraneous estimates for the entire migration potential from eastern enlargement, we also construct an upper-bound-scenario where the migrant labor force increases by as much as 70 percent. In each case the flow is composed unevenly across educational branches, with a more than proportional flow for low-skilled immigration.

We compare results obtained under wage-setting with the reference case of perfect labor markets. According to our simulation, the 6 percent inflow of the lower-boundscenario would generate an average short-run reduction of native wages by a mere 0.35 percent, with a less than average cut of 0.30 percent for high-skilled labor, and a cut of 0.39 percent for high-skilled natives. For foreign workers, the cuts are more pronounced, with 1.02 percent on average, and 1.31 percent ( 0.70 percent) for low-skilled (high-skilled) labor. In the long-run, with capital stocks adjusting to restore the initial marginal productivity of capital, the wage effects for natives turn into a gain by 0.07 percent for the average native. These are rather moderate effects, due to the small size of the shock considered. Scaling the shock up to the upper-bound-scenario, we arrive at short-run effects which are quite close to those reported by Borjas (2003), equal to a 4.16 percent wage cut for natives, despite imperfect substitutability between natives and foreigners. In the longrun, we again observe a wage increase for natives, as in Ottaviano \& Peri (2006), but much less pronounced, with an average increase of 0.78 percent, which is about a third of the gain calculated by Ottaviano \& Peri for the US. Finally, we calculate the wage and employment effects from our migration scenarios under the more realistic assumption of wage-setting with unemployment. By and large, we do observe the expected mitigation effect of wage setting on the wage effects that we have identified on a theoretical level.

Summarizing our results in a nutshell, relatively high substitution elasticities across educational attainments, and particularly across experience levels, limit the scope for complementarity between natives and immigrant workers. The lower-bound scenario for 
unrestricted labor movement from new member countries yields very small negative wage and employment effects for natives in the short-run, but no unemployment effects and moderate wage gains in the long-run. For an upper-bound scenario, the short-run wage effects are broadly comparable to those found by Borjas (2003) for the US, despite the fact that our results reveal imperfect substitutability between native and foreign labor. The long-run wage gains are significantly smaller than those obtained by Ottaviano \& Peri (2006) for the US. 


\section{References}

[1] Angrist, Joshua D. and Adriana D. Kugler (2003), "Protective or Couter-Productive? Labour Market Institutions and the Effect of Immigraiton on EU Natives" in Econoimc Journal 113 (June), F302-F331.

[2] Aydemir, Abdurrahman, George J. Borjas (2007). "Cross-Country Variation in the Impact of International Migration: Canada, Mexico, and the United States" in Journal of the European Economic Association 5 (4), 663-708.

[3] Berry, Albert R. and Ronald Soligo (1969). "Some Welfare Aspects of International Migration"in Journal of Political Economy 7 (5), 778-794.

[4] Blanchard, Olivier (2006). "European unemployment: the evolution of facts and ideas" in Economic Policy 21 (45), 5-59.

[5] Blanchard, Olivier (2007). "A Review of Richard Layard, Stephen Nickell, and Richard Jackman's Unemployment: Macroeconomic Performance and the Labour Market'" in Journal of Economic Literature, 45 (2), 410-418.

[6] Blanchflower, David G. and Andrew J. Oswald (2005), The Wage Curve Reloaded, NBER Working Paper No. 11338, Cambridge, MA.

[7] Bonin, Holger (2005). Wage and Employment Effects of Immigration to Germany: Evidence from a Skill Group Appraoch, IZA Discussion Paper 1875, Bonn.

[8] Borjas, George J. (1995). "The Economic Benefits from Immigration" in Journal of Economics Perspectives, 9 (2), 3-22.

[9] Borjas, Geroge J. (1999). "The Economic Analysis of Immigration," in O. Ashenfelter and D. Card, eds., Handbook of Labor Economics 3A, Amsterdam: Elsevier Science BV,, Ch. 28.

[10] Borjas, George J. (2003). "The Labor Demand Curve is Downward Sloping: Reexamining the Impact of Immigration on the Labor Market" in Quarterly Journal of Economics, CXVIII (4), 1335-1374.

[11] Borjas, George J., Richard Freeman and Larry Katz (1996). "Searching for the effect of Immigration on the Labor Market" in American Economic Review, Papers and Proceedings, 86 (2), 246-251. 
[12] Borjas, George J., Richard Freeman and Larry Katz (1997). "Imperfect Substitution between Nativess and Foreigers: A Reappraisal" in Brookings Papers on Economic Activity, 1997 (1), 1-90.

[13] Borjas, George J., Jeffrey Grogger and Gordon H. Hanson (2008). "How Much do Immigration and Trade Affect Labor Market Outcomes?" NBER Working Paper No. 13887, Cambridge, MA.

[14] Brücker, Herbert and Elke J. Jahn (2008) "Migration and the Wage Curve: A New Approach to Measure the Wage and Employment Effects of Migration", IZA Discussion Paper. No. 3423, Bonn

[15] Card, David (1990). "The Impact of the Mariel Boatlift on the Miami Labor Market" in Industrial and Labor Relation Review, XLIII, 245-257.

[16] Card, David and Thomas Lemieux (2001). "Can Falling Supply Explain the Rising Returns to College for Younger Men? A Cohort Based Analysis" in Quarterly Journal of Economics, CXVI, 705-746.

[17] D'Amuri, Francesco, Ottaviano, Gianmarco I.P. and Giovanni Peri (2008), "The Labor Market Impact of Immigration in Western Germany in the 1990's" NBER Working Paper No. 13851, Cambridge, MA.

[18] Ethier, Wilfried J. (1985). "International Trade and Labor Migration" in The American Economic Review 75 (September 1985), 691-707.

[19] Felbermayr, Gabriel and Wilhelm Kohler (2007). "Immigration and Native Welfare" in International Economic Review 48 (3), 731-760.

[20] Hamermesh, Daniel S. (1993). Labor Demand, Princeton, NJ: Princeton University Press.

[21] IOM (2005). World Migration 2005, International Organization for Migration, Geneva.

[22] Layard, R., S. Nickell and R. Jackman (2005). Unemployment: Macroeconomic Performance and the Labour Market, 2nd ed., Oxford: Oxford University Press.

[23] Manacorda, Marco, Alan Manning \& Jonathan Wadsworth (2006). "The Impact of Immigration on the Structure of Male Wages: Theory and Evidence from Britain", IZA Discussion Paper No. 2352, Bonn. 
[24] OECD (2007). "International Migration Outlook: Annual Report 2007 Edition" Organisation for Economic Co-operation and Development, Paris.

[25] Office for National Statistics. Social and Vital Statistics Division and Northern Ireland Statistics and Research Agency. Central Survey Unit, Quarterly Labour Force Survey, October - December, 2003. Colchester, Essex: UK Data Archive, August 2006. SN: 5423.

[26] Office for National Statistics. Social and Vital Statistics Division and Northern Ireland Statistics and Research Agency. Central Survey Unit, Quarterly Labour Force Survey, October - December, 2006. Colchester, Essex: UK Data Archive, April 2007. SN: 5609.

[27] Ottaviano, Gianmarco I.P. and Peri Giovanni (2006). Rethinking the Effects of Immigration on Wages, NBER Working Paper No. 12497, Cambridge, MA.

[28] Sinn, Hans-Werner, Gebhard Flaig, Martin Werding, Sonja Munz, Nicola Düll and Herbert Hofmann (2001): EU-Erweiterung und Arbeitskräftemigration Wege zu einer schrittweisen Annäherung der Arbeitsmärkte. Studie im Auftrag des Bundesministeriums für Arbeit und Sozialordnung. Ifo Institut, München.

[29] UN-DESA (2004). World Economic and Social Survey 2004: International Migration, United Nations, New York.

[30] Zaiceva, Anzelika (2006). "Reconciling the Estimates of Potential Migration into the Enlarged European Union", IZA Discussion Paper. No. 2519, Bonn 
Table 1: Summary Statistics (fully employed workers, Western Germany)

\begin{tabular}{|c|c|c|c|c|c|c|}
\hline \multirow[b]{2}{*}{$\begin{array}{r}\operatorname{Immi}-/ \\
\text { grant }(\mathrm{M}) \\
\text { Native }(\mathrm{N})\end{array}$} & \multirow[b]{2}{*}{$\begin{array}{r}\text { Experience } \\
\text { (years) }\end{array}$} & \multirow[b]{2}{*}{$\begin{array}{r}\text { Education } \\
\text { (class) }\end{array}$} & \multicolumn{2}{|c|}{$\begin{array}{l}\text { Sample statistics } \\
\text { (SOEP) }\end{array}$} & \multicolumn{2}{|c|}{$\begin{array}{l}\text { Population statistics } \\
\text { (Micro-census) }\end{array}$} \\
\hline & & & $\begin{array}{l}\text { Avg. } \\
\text { number } \\
\text { of obs. }\end{array}$ & $\begin{array}{l}\text { Min. } \\
\text { number of } \\
\text { obs./year }\end{array}$ & $\begin{array}{l}\text { Avg. cell } \\
\text { size (in } \\
\text { thousand) }\end{array}$ & $\begin{array}{r}\text { Growth rate } \\
1984-2004 \\
\text { (percent) }\end{array}$ \\
\hline M & $0-9$ & $1 \& 2$ & 175 & 76 & 479.7 & 41.02 \\
\hline M & $0-9$ & 3 & 185 & 102 & 501.1 & 97.5 \\
\hline M & $0-9$ & $4 \& 5$ & 41 & 25 & 129.7 & 405.5 \\
\hline M & $0-9$ & 6 & 41 & 14 & 162.8 & 134.5 \\
\hline M & $10-19$ & $1 \& 2$ & 163 & 76 & 276.4 & -46.1 \\
\hline M & $10-19$ & 3 & 138 & 91 & 299.6 & 23.4 \\
\hline M & $10-19$ & $4 \& 5$ & 41 & 19 & 85.0 & 63.4 \\
\hline M & 10-19 & 6 & 47 & 8 & 110.5 & 590.1 \\
\hline M & $20-29$ & $1 \& 2$ & 156 & 57 & 274.9 & -22.3 \\
\hline M & $20-29$ & 3 & 110 & 75 & 300.0 & 12.5 \\
\hline M & $20-29$ & $4 \& 5$ & 28 & 8 & 85.0 & 140.6 \\
\hline M & $20-29$ & 6 & 30 & 8 & 110.5 & 585.1 \\
\hline M & $>29$ & $1 \& 2$ & 136 & 67 & 251.8 & -1.5 \\
\hline M & $>29$ & 3 & 70 & 27 & 231.0 & 22.8 \\
\hline M & $>29$ & $4 \& 5$ & 13 & 6 & 59.5 & 229.3 \\
\hline $\mathrm{M}$ & $>29$ & 6 & 34 & 5 & 245.5 & 569.3 \\
\hline SUM M & & & & & $3,756.6$ & \\
\hline $\mathrm{N}$ & $0-9$ & $1 \& 2$ & 180 & 125 & $1,999.2$ & -40.5 \\
\hline $\mathrm{N}$ & $0-9$ & 3 & 613 & 468 & $3,833.1$ & -38.4 \\
\hline $\mathrm{N}$ & $0-9$ & $4 \& 5$ & 205 & 106 & $1,259.5$ & 2.71 \\
\hline $\mathrm{N}$ & 0-9 & 6 & 219 & 103 & $1,391.5$ & 67.4 \\
\hline $\mathrm{N}$ & $10-19$ & $1 \& 2$ & 163 & 105 & 891.1 & -43.0 \\
\hline $\mathrm{N}$ & $10-19$ & 3 & 645 & 322 & $3,393.6$ & 18.5 \\
\hline $\mathrm{N}$ & $10-19$ & $4 \& 5$ & 191 & 67 & $1,096.7$ & 90.1 \\
\hline $\mathrm{N}$ & $10-19$ & 6 & 205 & 84 & $1,252.3$ & 79.5 \\
\hline $\mathrm{N}$ & $20-29$ & $1 \& 2$ & 144 & 99 & 844.4 & -24.2 \\
\hline $\mathrm{N}$ & $20-29$ & 3 & 477 & 286 & $2,608.1$ & 16.2 \\
\hline $\mathrm{N}$ & $20-29$ & $4 \& 5$ & 108 & 59 & 662.8 & 18.9 \\
\hline $\mathrm{N}$ & $20-29$ & 6 & 150 & 20 & 842.4 & 139.3 \\
\hline $\mathrm{N}$ & $>29$ & $1 \& 2$ & 142 & 64 & $1,033.8$ & -53.0 \\
\hline $\mathrm{N}$ & $>29$ & 3 & 353 & 153 & $2,360.7$ & 2.0 \\
\hline $\mathrm{N}$ & $>29$ & $4 \& 5$ & 77 & 45 & 584.8 & 6.0 \\
\hline $\mathrm{N}$ & $>29$ & 6 & 87 & 22 & 536.4 & 130.2 \\
\hline SUM M & & & & & $24,590.3$ & \\
\hline SUM M+N & & & & & $28,346.9$ & \\
\hline
\end{tabular}




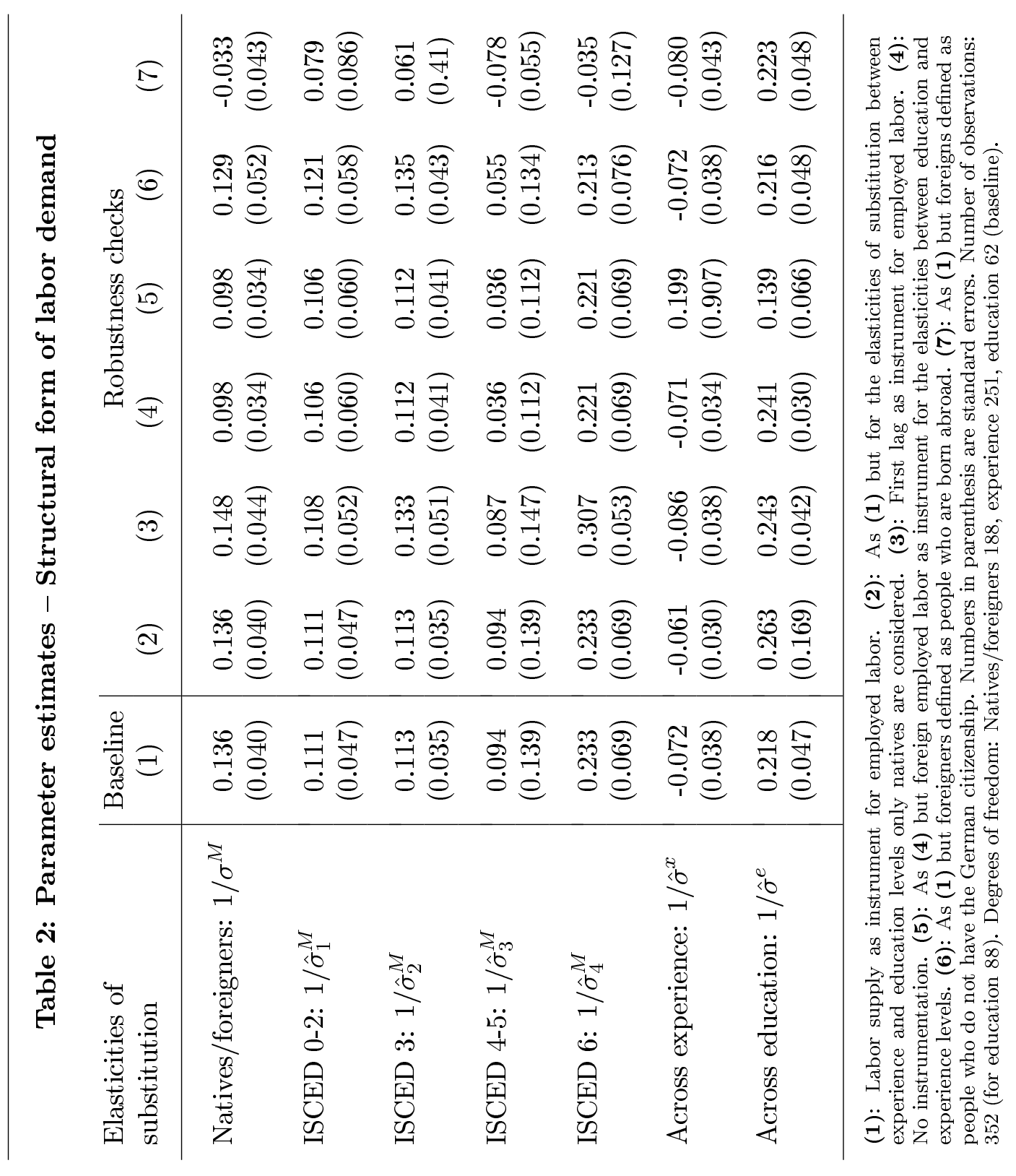


Table 3: Elasticities of q-complementarity between migrants and natives

\begin{tabular}{llcccc}
$\begin{array}{c}\text { Educational } \\
\text { attainment }\end{array}$ & $\begin{array}{c}\text { Experience } \\
\text { level }\end{array}$ & $\begin{array}{c}\text { Direct } \\
\text { elasticity } \\
\text { levels }\end{array}$ & $\begin{array}{c}\text { Across } \\
\text { experience }\end{array}$ & $\begin{array}{c}\text { Across } \\
\text { educational } \\
\text { attainment }\end{array}$ & $\begin{array}{c}\text { "Received" } \\
\text { comple- } \\
\text { mentarity }\end{array}$ \\
\hline ISCED 1 - 2 & $0-10$ years & 0.0007 & -0.0182 & -0.0055 & -0.0943 \\
& $11-20$ years & 0.0111 & -0.0127 & -0.0038 & -0.0895 \\
& $21-30$ years & 0.0040 & -0.0146 & -0.0044 & -0.0977 \\
& $\geq 31$ years & 0.0070 & -0.0132 & -0.0040 & -0.0985 \\
ISCED 3 & $0-10$ years & -0.0030 & -0.0160 & -0.0097 & -0.0826 \\
& $11-20$ years & -0.0062 & -0.0132 & -0.0080 & -0.0886 \\
& $21-30$ years & -0.0050 & -0.0120 & -0.0073 & -0.0903 \\
ISCED 4 - 5 5 - 10 years & 0.0042 & -0.0116 & -0.0054 & -0.0765 \\
& $11-20$ years & -0.0009 & -0.0076 & -0.0029 & -0.0849 \\
& $21-30$ years & 0.0027 & -0.0090 & -0.0034 & -0.0829 \\
& $\geq 31$ years & 0.0036 & -0.0060 & -0.0023 & -0.0866 \\
ISCED 6 & $0-10$ years & 0.0113 & -0.0110 & -0.0059 & -0.0772 \\
& $11-20$ years & 0.0098 & -0.0187 & -0.0101 & -0.0768 \\
& $21-30$ years & 0.0125 & -0.0133 & -0.0072 & -0.0792 \\
& $\geq 31$ years & 0.0282 & -0.0155 & -0.0084 & -0.0653 \\
\hline
\end{tabular}

Elasticities of substitution used in calculations: Across educational groups, $\sigma_{e}=4.6$. Across experience levels, $\sigma_{x}=100$. Native versus foreign labor, $\sigma_{e}^{M}$ : for ISCED $1+2, \sigma_{e}^{M}=9.0$; for ISCED $3, \sigma_{e}^{M}=10.6$; for ISCED $4+5, \sigma_{e}^{M}=8.9$; for ISCED $6, \sigma_{e}^{M}=4.3$. 
Table 4: Parameter estimates - wage curve

\begin{tabular}{|c|c|c|c|c|}
\hline & \multicolumn{4}{|c|}{ Pooled OLS } \\
\hline & \multicolumn{2}{|c|}{ Short-run } & \multicolumn{2}{|c|}{ Long-run } \\
\hline Employment ratio & $\begin{array}{c}0.084 \\
(0.043)\end{array}$ & & $\begin{array}{c}0.550 \\
(0.144)\end{array}$ & \\
\hline Unemployment rate & & $\begin{array}{c}-0.108 \\
(0.052)\end{array}$ & & $\begin{array}{c}-0.703 \\
(0.180)\end{array}$ \\
\hline Lagged wage & $\begin{array}{c}0.839 \\
(0.045)\end{array}$ & $\begin{array}{c}0.839 \\
(0.045)\end{array}$ & & \\
\hline
\end{tabular}

Arellano-Bond/Random-effects*

Short-run Long-run

\begin{tabular}{|c|c|c|c|}
\hline Employment ratio & $\begin{array}{c}0.004 \\
(0.044)\end{array}$ & & \\
\hline Unemployment rate & & $\begin{array}{c}-0.014 \\
(0.050)\end{array}$ & $\begin{array}{l}-0.186 \\
(0.067)\end{array}$ \\
\hline \multirow[t]{2}{*}{ Lagged wage } & $\begin{array}{c}0.336 \\
(0.050)\end{array}$ & $\begin{array}{c}0.336 \\
(0.050)\end{array}$ & \\
\hline & \multicolumn{3}{|c|}{$\begin{array}{l}\text { Fixed-effects estimator } \\
\text { Long-run }\end{array}$} \\
\hline Employment ratio & & & \\
\hline Unemployment rate & & & $\begin{array}{l}-0.143 \\
(0.064)\end{array}$ \\
\hline
\end{tabular}

Log-linear specification (except unemployment rate). Dependent variable: wage rate. Standard errors (in parentheses) are adjusted for clustering in education-experiencenation groups. All regressions include education-specific time trends. Number of observations: 672. * Short-run: Arellano-Bond. Long-run: Random-effects estimator. 


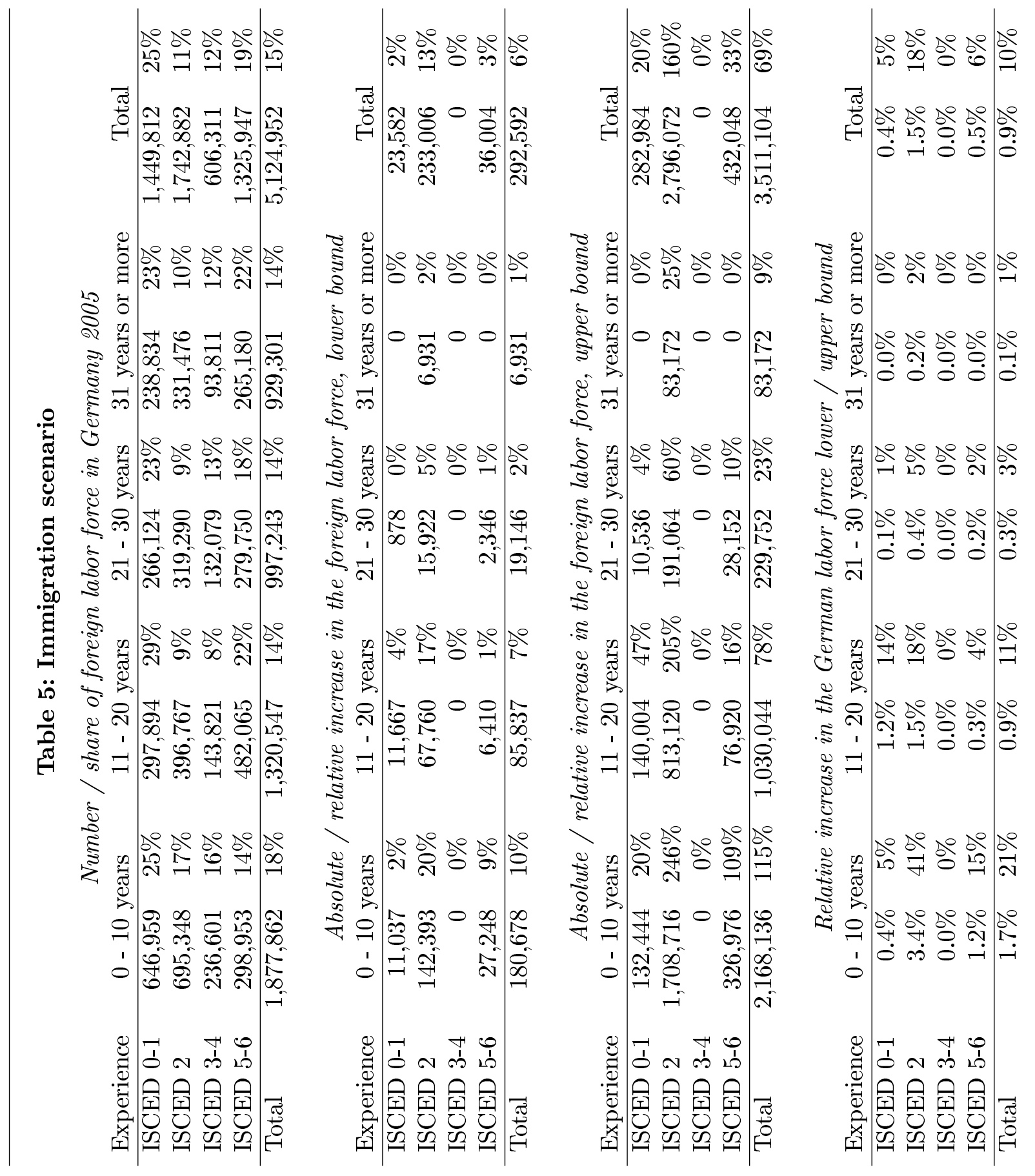




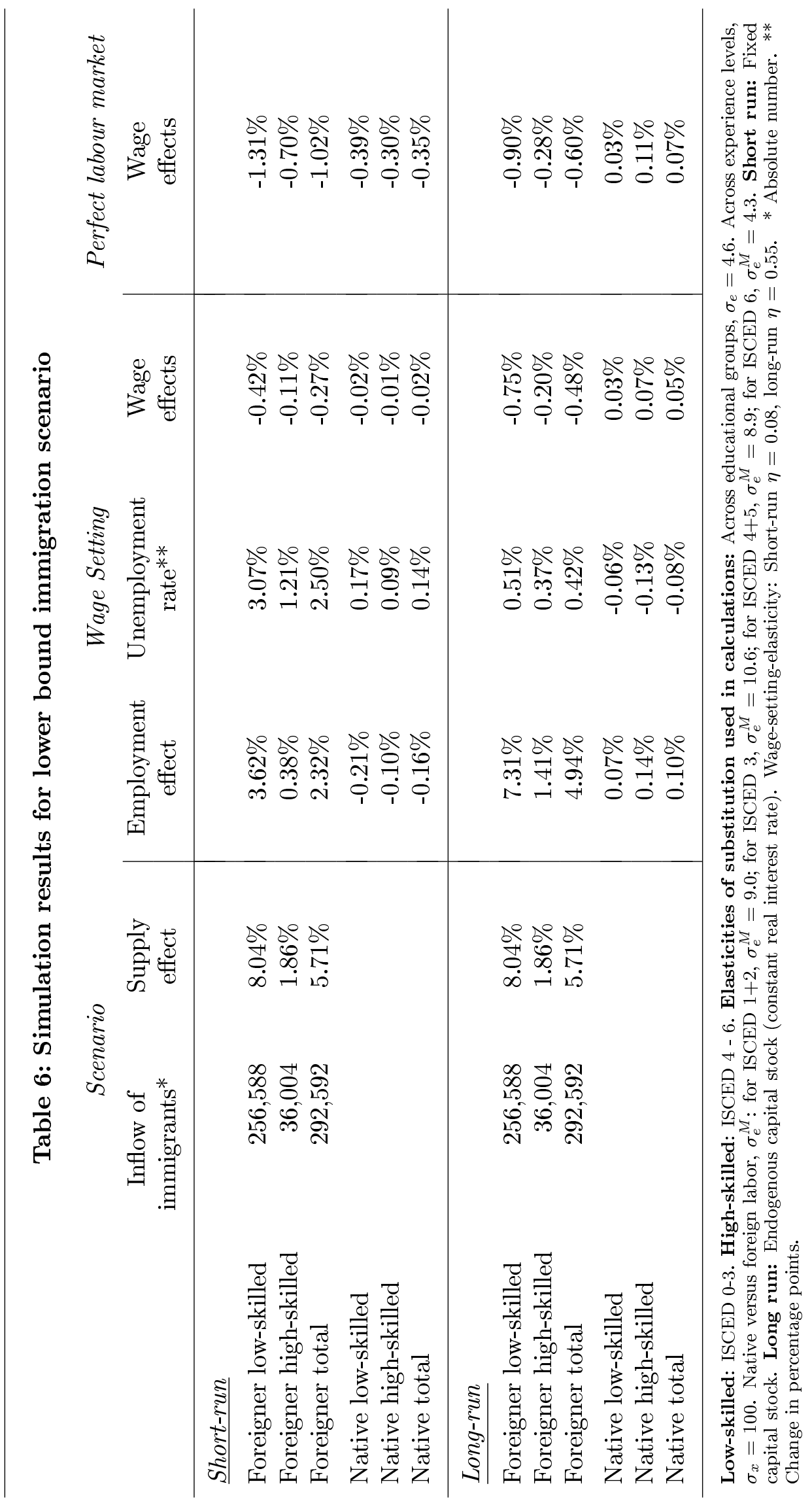




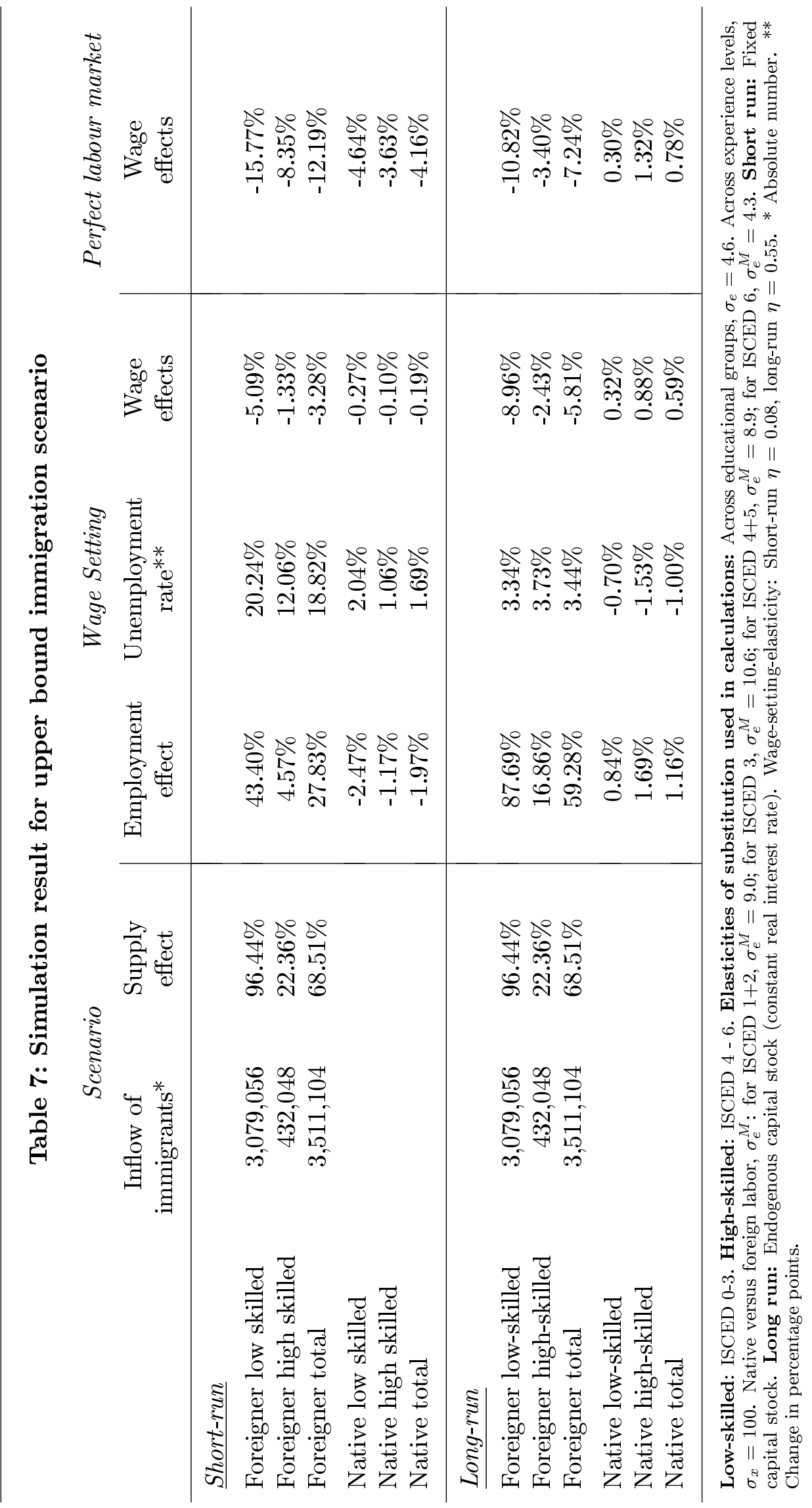




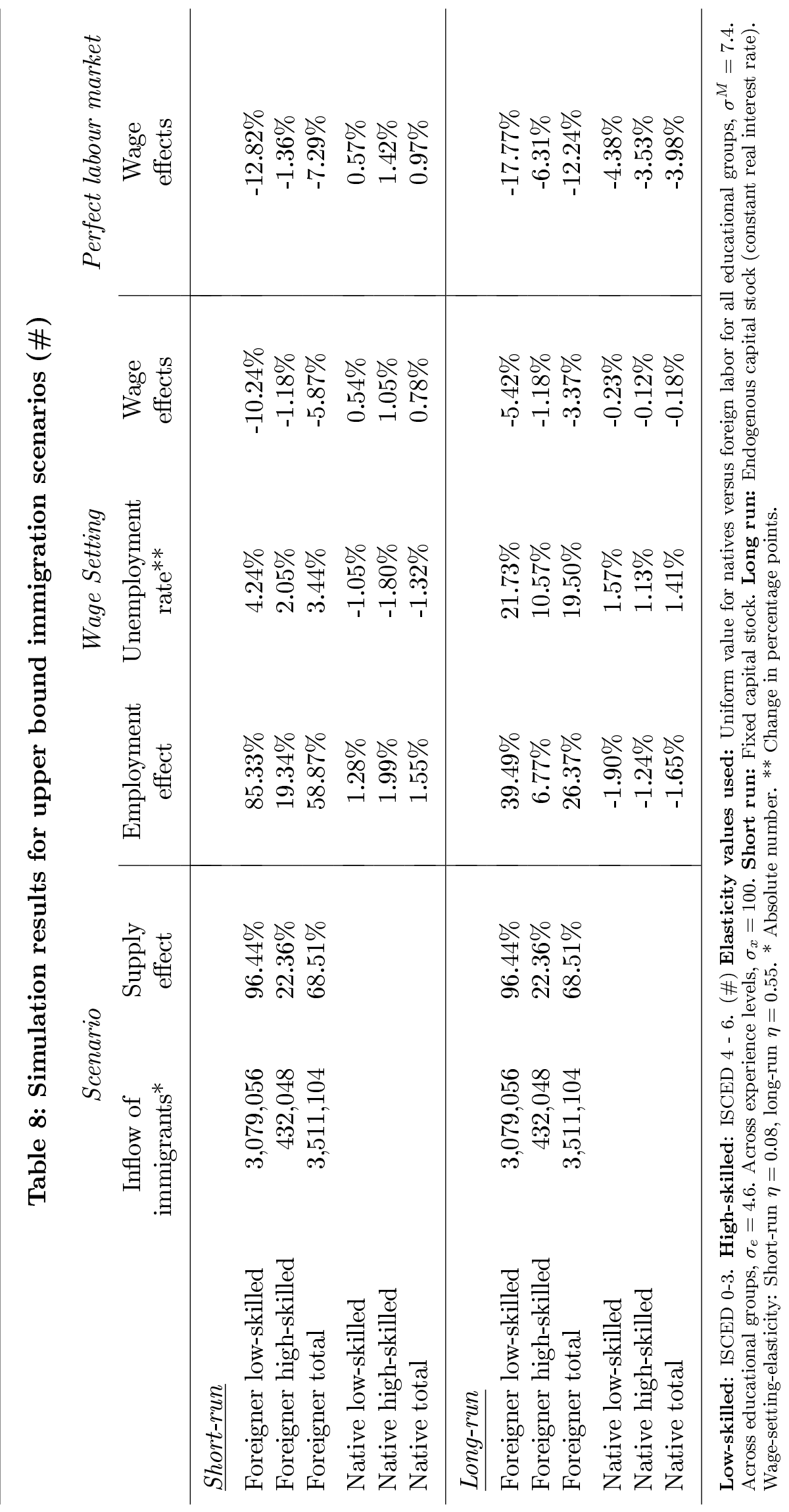




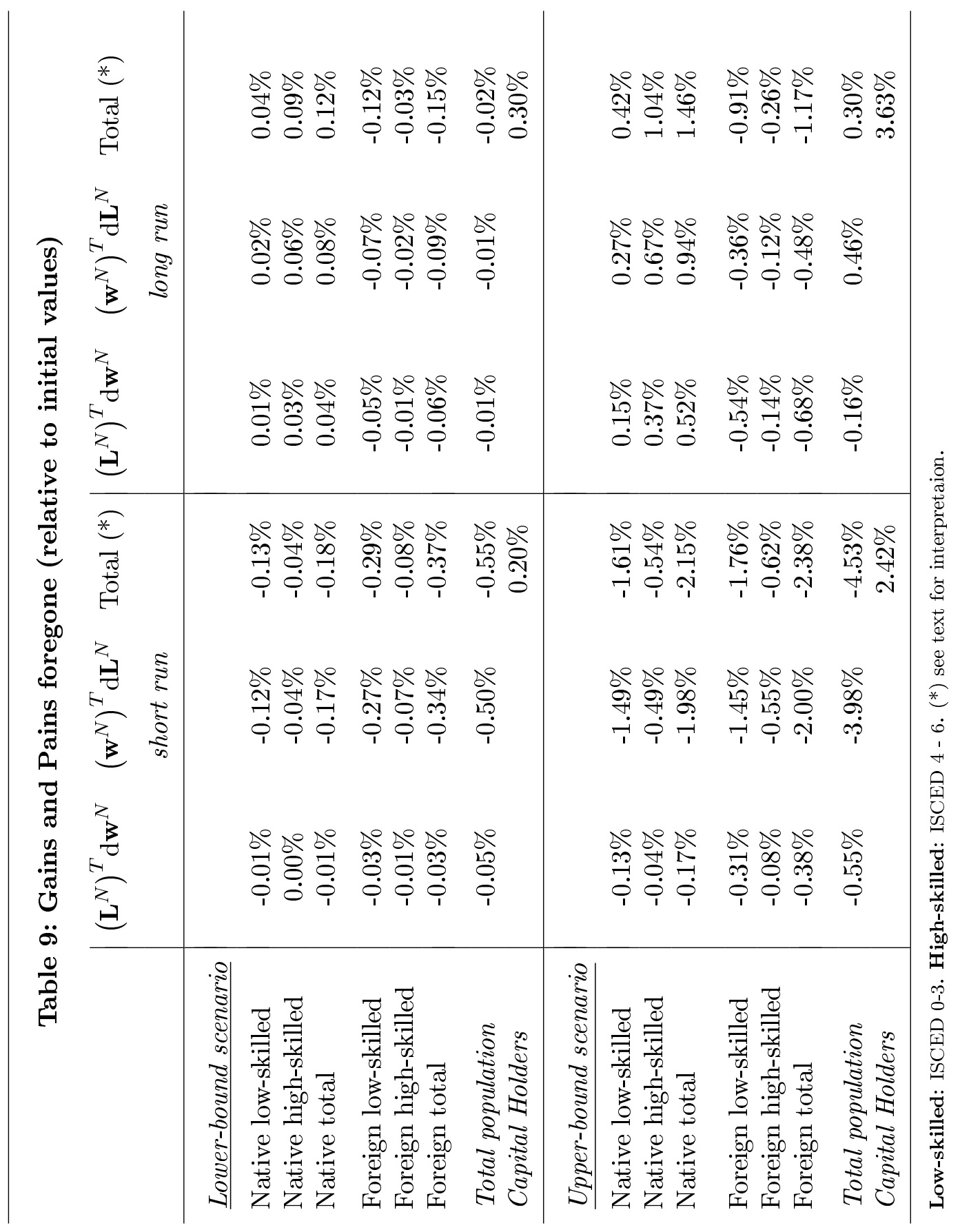




\section{CESifo Working Paper Series}

for full list see www.cesifo-group.org/wp

(address: Poschingerstr. 5, 81679 Munich, Germany, office@cesifo.de)

2257 C.A.E. Goodhart, The Regulatory Response to the Financial Crisis, March 2008

2258 Stefan Bauernschuster, Oliver Falck and Stephan Heblich, The Impact of Continuous Training on a Firm's Innovations, March 2008

2259 Michael Grimm and Stephan Klasen, Geography vs. Institutions at the Village Level, March 2008

2260 Fwu-Ranq Chang, Property Insurance, Portfolio Selection and their Interdependence, March 2008

2261 J. Atsu Amegashie and Marco Runkel, The Paradoxes of Revenge in Conflicts, March 2008

2262 Hans Jarle Kind, Marko Koethenbuerger and Guttorm Schjelderup, Efficiency Enhancing Taxation in Two-sided Markets, March 2008

2263 M. Hashem Pesaran, Til Schuermann and L. Vanessa Smith, Forecasting Economic and Financial Variables with Global VARs, March 2008

2264 Volker Grossmann, Entrepreneurial Innovation and Sustained Long-run Growth without Weak or Strong Scale Effects, March 2008

2265 Robert S. Chirinko and Huntley Schaller, The Irreversibility Premium, March 2008

2266 Andrea Galeotti and José Luis Moraga-González, Platform Intermediation in a Market for Differentiated Products, April 2008

2267 Torben M. Andersen and Michael Svarer, The Role of Workfare in Striking a Balance between Incentives and Insurance in the Labour Market, April 2008

2268 Harald Badinger, Cyclical Fiscal Policy, Output Volatility, and Economic Growth, April 2008

2269 Thomas Aronsson and Erkki Koskela, Outsourcing and Optimal Nonlinear Taxation: A Note, April 2008

2270 Gary E. Bolton, Claudia Loebbecke and Axel Ockenfels, How Social Reputation Networks Interact with Competition in Anonymous Online Trading: An Experimental Study, April 2008

2271 Nikolaus Wolf, Scylla and Charybdis. Explaining Europe’s Exit from Gold, January 1928 - December 1936, April 2008 
2272 Michael Funke and Marc Gronwald, The Undisclosed Renminbi Basket: Are the Markets Telling us something about where the Renminbi - US Dollar Exchange Rate is Going?, April 2008

2273 Thor Olav Thoresen and Annette Alstadsæter, Shifts in Organizational Form under a Dual Income Tax System, April 2008

2274 Helge Berger and Volker Nitsch, Too many Cooks? Committees in Monetary Policy, April 2008

2275 Yin-Wong Cheung and Eiji Fujii, Deviations from the Law of One Price in Japan, April 2008

2276 Michael S. Michael, Sajal Lahiri and Panos Hatzipanayotou, Integrated Reforms of Indirect Taxes in the Presence of Pollution, April 2008

2277 Bas Jacobs, Is Prescott Right? Welfare State Policies and the Incentives to Work, Learn and Retire, April 2008

2278 Burkhard Heer and Alfred Maußner, Value Function Iteration as a Solution Method for the Ramsey Model, April 2008

2279 Jarko Fidrmuc and Christa Hainz, Integrating with their Feet: Cross-Border Lending at the German-Austrian Border, April 2008

2280 Kristof Dascher and Alexander Haupt, The Political Economy of Regional Integration Projects at Borders where Rich and Poor Meet: The Role of Cross-Border Shopping and Community Sorting, April 2008

2281 Katrin Assenmacher-Wesche and M. Hashem Pesaran, A VECX* Model of the Swiss Economy, April 2008

2282 Christophe Rault, Robert Sova and Ana Maria Sova, Modeling International Trade Flows between CEEC and OECD Countries, April 2008

2283 Timo Boppart, Josef Falkinger, Volker Grossmann, Ulrich Woitek and Gabriela Wüthrich, Qualifying Religion: The Role of Plural Identities for Educational Production, April 2008

2284 Armin Falk, David Huffman and W. Bentley MacLeod, Institutions and Contract Enforcement, April 2008

2285 Axel Dreher and Stefan Voigt, Does Membership in International Organizations Increase Governments' Credibility? Testing the Effects of Delegating Powers, April 2008

2286 Xavier Freixas and Bruno M. Parigi, Lender of Last Resort and Bank Closure Policy, April 2008 
2287 Regina Dionisius, Samuel Muehlemann, Harald Pfeifer, Günter Walden, Felix Wenzelmann and Stefan C. Wolter, Cost and Benefit of Apprenticeship Training - A Comparison of Germany and Switzerland, April 2008

2288 Francesco Daveri and Cecilia Jona-Lasinio, Off-Shoring and Productivity Growth in the Italian Manufacturing Industries, April 2008

2289 Mikael Priks, Do Surveillance Cameras Affect Unruly Behavior? A Close Look at Grandstands, April 2008

2290 Marianna Belloc and Daniela Federici, A Two-Country NATREX Model for the Euro/Dollar, April 2008

2291 Nicolas Treich, The Value of a Statistical Life under Ambiguity Aversion, April 2008

2292 J. Atsu Amegashie, Socially-Tolerable Discrimination, April 2008

2293 M. Hashem Pesaran and Andreas Pick, Forecasting Random Walks Under Drift Instability, April 2008

2294 Steven Brakman, Gus Garita, Harry Garretsen and Charles van Marrewijk, Unlocking the Value of Cross-Border Mergers and Acquisitions, May 2008

2295 Eric O’N. Fisher and Kathryn G. Marshall, The Structure of the American Economy, May 2008

2296 Claudia M. Buch and Martin Schlotter, Regional Origins of Employment Volatility: Evidence from German States, May 2008

2297 Helmuth Cremer, Philippe De Donder, Dario Maldonado and Pierre Pestieau, Taxing Sin Goods and Subsidizing Health Care, May 2008

2298 Reinhilde Veugelers and Frederick van der Ploeg, Reforming European Universities: Scope for an Evidence-Based Process, May 2008

2299 Jon H. Fiva and Lars J. Kirkebøen, Does the Housing Market React to New Information on School Quality?, May 2008

2300 Tina Klautke and Alfons J. Weichenrieder, Interest Income Tax Evasion, the EU Savings Directive, and Capital Market Effects, May 2008

2301 Harald Badinger and Peter Egger, GM Estimation of Higher Order Spatial Autoregressive Processes in Panel Data Error Component Models, May 2008

2302 Jan K. Brueckner, Slot-Based Approaches to Airport Congestion Management, May 2008

2303 Sören Blomquist, Vidar Christiansen and Luca Micheletto, Public Provision of Private Goods and Nondistortionary Marginal Tax Rates, May 2008 
2304 Dan Anderberg and Alessandro Balestrino, The Political Economy of Post-Compulsory Education Policy with Endogenous Credit Constraints, May 2008

2305 Tomer Blumkin, Yoram Margalioth and Efraim Sadka, The Role of Stigma in the Design of Welfare Programs, May 2008

2306 Vesa Kanniainen and Paolo M. Panteghini, Tax Neutrality: Illusion or Reality? The Case of Entrepreneurship, May 2008

2307 Thomas Dohmen, Armin Falk, David Huffman and Uwe Sunde, The Intergenerational Transmission of Risk and Trust Attitudes, May 2008

2308 Guglielmo Maria Caporale and Mario Cerrato, Using Chebyshev Polynomials to Approximate Partial Differential Equations, May 2008

2309 Peter Egger and Doina Maria Radulescu, Labour Taxation and Foreign Direct Investment, May 2008

2310 Laurent Linnemer, Dissipative Advertising Signals Quality even without Repeat Purchases, May 2008

2311 Jordi Jofre-Monseny and Albert Solé-Ollé, Which Communities should be afraid of Mobility? The Effects of Agglomeration Economies on the Sensitivity of Firm Location to Local Taxes, May 2008

2312 Andreas Haufler and Ferdinand Mittermaier, Unionisation Triggers Tax Incentives to Attract Foreign Direct Investment, May 2008

2313 Ronel Elul and Piero Gottardi, Bankruptcy: Is it enough to Forgive or must we also Forget?, May 2008

2314 Andreas Irmen and Johanna Kuehnel, Productive Government Expenditure and Economic Growth, May 2008

2315 Beate Henschel, Carsten Pohl and Marcel Thum, Demographic Change and Regional Labour Markets: The Case of Eastern Germany, May 2008

2316 Gabriel Felbermayr, Wido Geis and Wilhelm Kohler, Restrictive Immigration Policy in Germany: Pains and Gains Foregone?, May 2008 